Sampling and Analysis Instruction for Installation of UPR-100-N-17

Bioremediation Wells and Performance of Bioventing Pilot Tests

\title{
December 2008
}

\section{Washington Closure Hanford}

Prepared for the U.S. Department of Energy, Richland Operations Office Office of Assistant Manager for River Corridor

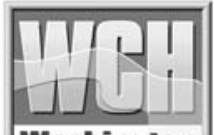


TRADEMARK DISCLAIMER

Reference herein to any specific commercial product, process, or service by trade name, trademark, manufacturer, or otherwise, does not necessarily constitute or imply its endorsement, recommendation, or favoring by the United States Government or any agency thereof or its contractors or subcontractors.

This report has been reproduced from the best available copy. Available in paper copy.

Available for a processing fee to U.S. Department of Energy and its contractors in paper from:

U.S. Department of Energy

Office of Scientific and Technical Information

P.O. Box 62

Oak Ridge, TN 37831-0062

Telephone: (865) 576-8401

Facsimile: (865) 576-5728

E-mail: reports@osti.gov

Available for sale to the public from:

U.S. Department of Commerce

National Technical Information Service

5285 Port Royal Road

Springfield, VA 22161

Telephone: (800) 553-6847

Facsimile: (703) 605.6900

E-mail: orders@ntis.fedworld.gov

Online ordering: http://www.ntis.gov/ordering.htm

Printed in the United States of America 


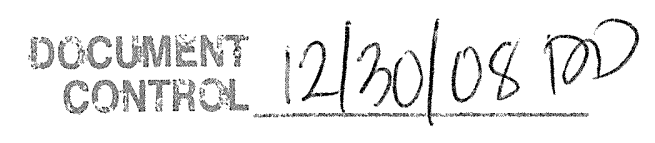

WCH-323

Rev. 0

\section{STANDARD APPROVAL PAGE}

Title: $\quad$ Sampling and Analysis Instruction for Installation of UPR-100-N-17 Bioremediation Wells and Performance of Bioventing Pilot Tests

Author Name: W. S. Thompson

Approval: $\quad$ R. A. Carlson, Remediation Engineering Manager
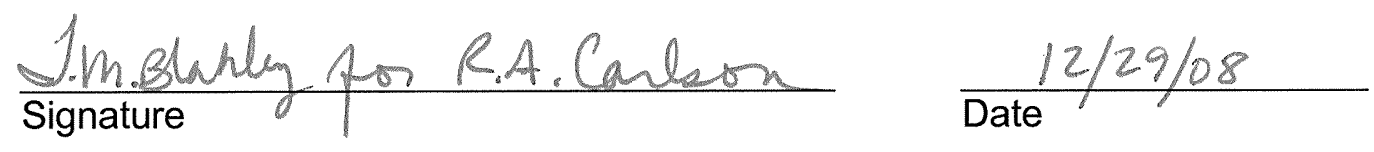

The approval signature on this page indicates that this document has been authorized for information release to the public through appropriate channels. No other forms or signatures are required to document this information release. 
WCH-323

Rev. 0

River Corridor Closure Contract

\section{Sampling and Analysis Instruction for Installation of UPR-100-N-17 Bioremediation Wells and Performance of Pilot Tests}

December 2008

Author:

W. S. Thompson 


\section{TABLE OF CONTENTS}

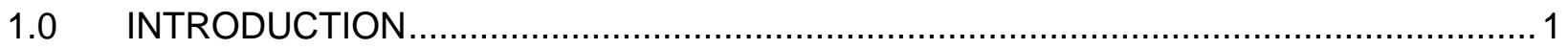

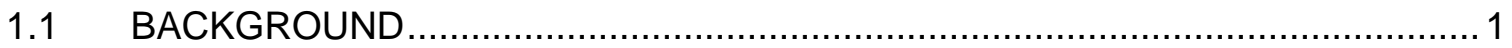

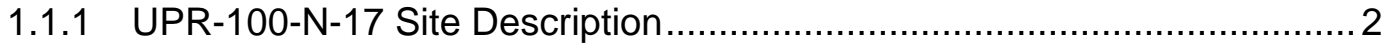

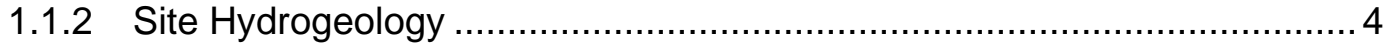

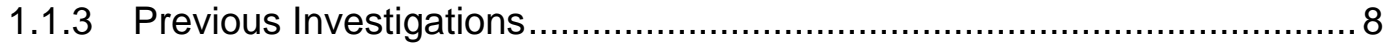

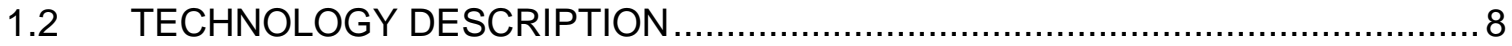

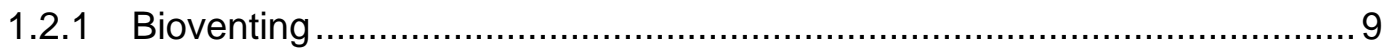

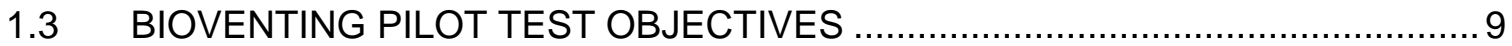

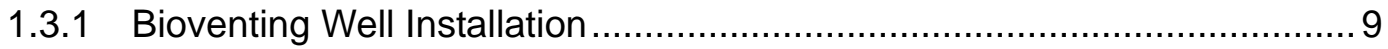

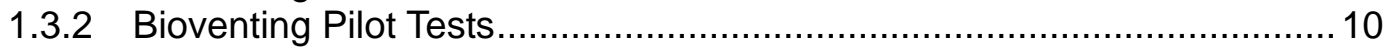

1.3.3 Data Requirements for Bioventing Pilot Test ................................ 10

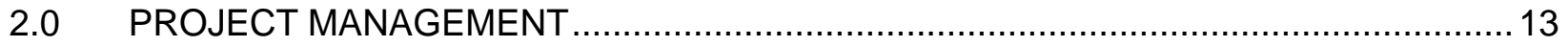

2.1 PROJECT/TASK ORGANIZATION ....................................................... 13

2.2 QUALITY OBJECTIVES AND CRITERIA FOR MEASUREMENT DATA ........... 13

2.2.1 Laboratory Measurements.............................................................. 13

2.2.2 Field Measurements ................................................................... 16

2.3 SPECIAL TRAINING REQUIREMENTS AND CERTIFICATIONS ..................... 16

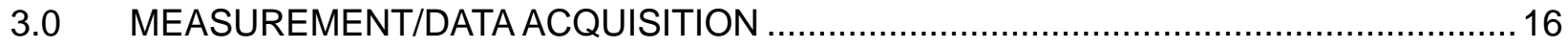

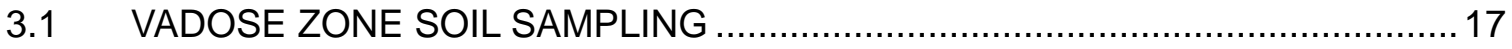

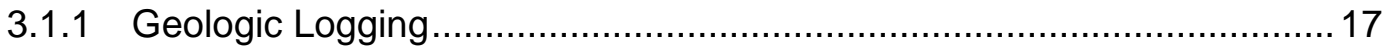

3.1.2 Split-Spoon Soil Sample Collection ............................................... 17

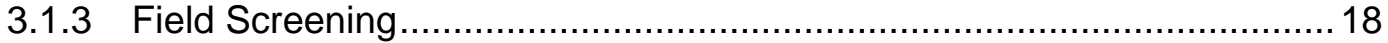

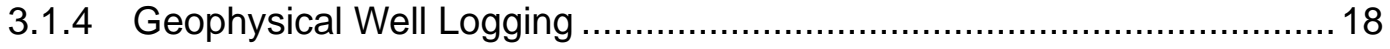

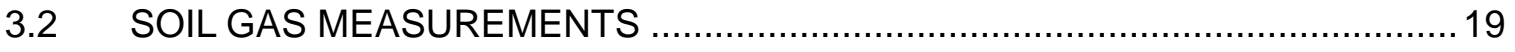

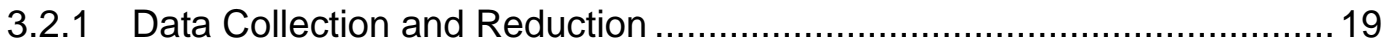

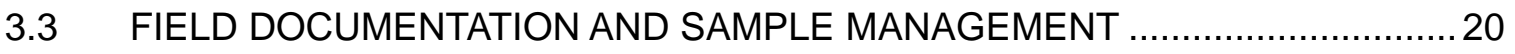

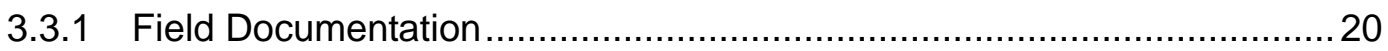

3.3.2 Sample Custody and Transport .................................................. 21

3.3.3 Sample Preservation, Containers, and Holding Times ......................... 21

Sampling and Analysis Instruction for Installation of UPR-100-N-17 Bioremediation Wells and Performance of Bioventing Pilot Tests 


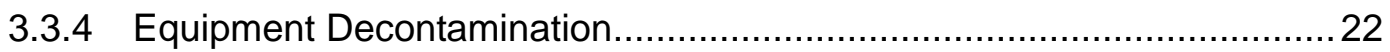

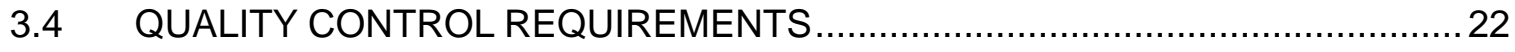

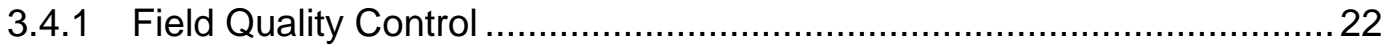

3.4.2 Laboratory Quality Control......................................................... 23

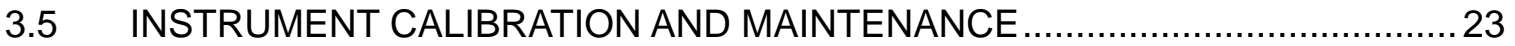

3.5.1 Field Measurement Instruments …................................................. 23

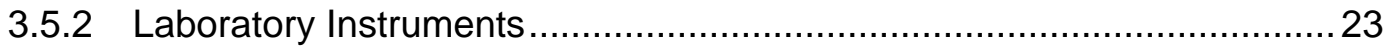

3.6 DATA VALIDATION AND VERIFICATION ................................................. 23

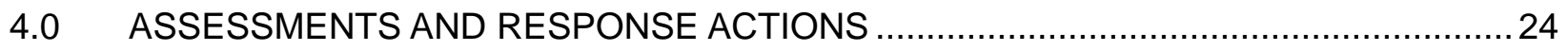

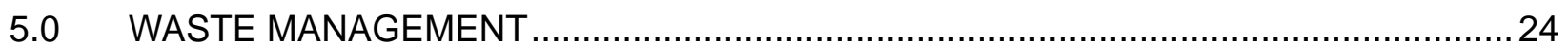

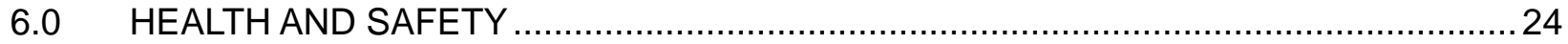

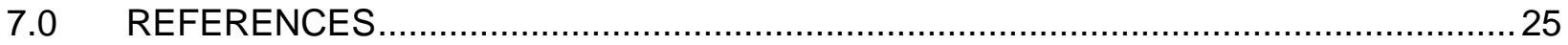

\section{FIGURES}

1. Map Showing Location of UPR-100-N-17 Waste Site ............................................ 2

2. 1968 Photograph of 166-N Tank Farm Facility. .................................................... 3

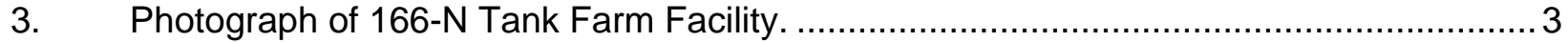

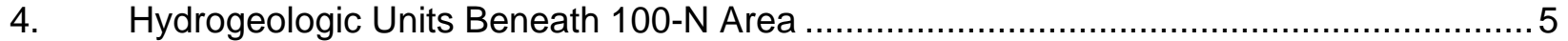

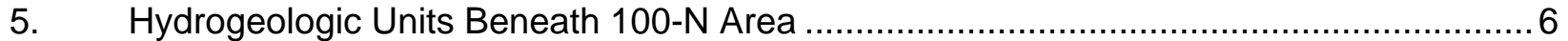

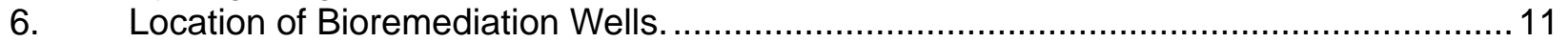

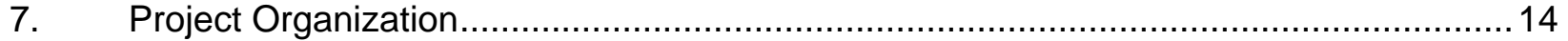

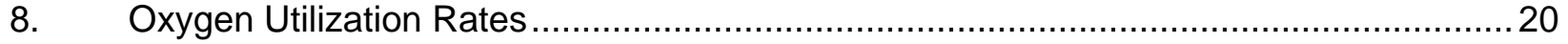

\section{TABLES}

1. Characterization Parameters for Bioremediation/Bioventing ................................. 12

2. Analytical Performance Requirements - Laboratory ........................................... 15

3. Analytical Performance Requirements - Field Measurements. ................................ 16

4. Vadose Zone Soil Sampling Requirements. ..................................................... 18

5. Sample Preservation, Container, and Holding Time Guidelines. ...............................21 


\section{ACRONYMS}

$\begin{array}{ll}\text { BTEX } & \text { benzene, ehtylbenzene, toluene, and xylenes } \\ \text { CFR } & \text { Code of Federal Regulations } \\ \text { CFU } & \text { colony forming unit } \\ \text { CHPRC } & \text { CH2MHill Plateau Remediation Contractor } \\ \text { Ecology } & \text { Washington State Department of Ecology } \\ \text { ERC } & \text { Environmental Restoration Contractor } \\ \text { EPA } & \text { Environmental Projection Agency } \\ \text { ERDF } & \text { Environmental Restoration Disposal Facility } \\ \text { FID } & \text { flame ionization detector } \\ \text { FY } & \text { fiscal year } \\ \text { LEL } & \text { lower explosive limit } \\ \text { NPO } & \text { nuclear process operator } \\ \text { PID } & \text { photoionization detector } \\ \text { QA } & \text { quality assurance } \\ \text { QC } & \text { quality control } \\ \text { RCRA } & \text { Resource Conservation and Recovery Act of 1976 } \\ \text { RDR/RAWP } & \text { remedial design report/remedial action work plan } \\ \text { ROD } & \text { record of decision } \\ \text { RPM } & \text { Remedial Project Manager } \\ \text { SAI } & \text { sampling and analysis instruction } \\ \text { SOP } & \text { standard operating procedure } \\ \text { TPH } & \text { total petroleum hydrocarbon } \\ \text { VOC } & \text { volatile organic compound } \\ \text { WAC } & \text { Washington Administrative Code } \\ \text { WCH } & \text { Washington Closure Hanford } \\ \text { WIDS } & \text { Waste Information Data System } \\ & \end{array}$




\section{METRIC CONVERSION CHART}

\begin{tabular}{|c|c|c|c|c|c|}
\hline \multicolumn{3}{|c|}{ Into Metric Units } & \multicolumn{3}{|c|}{ Out of Metric Units } \\
\hline If You Know & Multiply By & To Get & If You Know & Multiply By & To Get \\
\hline Length & & & Length & & \\
\hline inches & 25.4 & millimeters & millimeters & 0.039 & inches \\
\hline inches & 2.54 & centimeters & centimeters & 0.394 & inches \\
\hline feet & 0.305 & meters & meters & 3.281 & feet \\
\hline yards & 0.914 & meters & meters & 1.094 & yards \\
\hline miles & 1.609 & kilometers & kilometers & 0.621 & miles \\
\hline Area & & & Area & & \\
\hline sq. inches & 6.452 & sq. centimeters & sq. centimeters & 0.155 & sq. inches \\
\hline sq. feet & 0.093 & sq. meters & sq. meters & 10.76 & sq. feet \\
\hline sq. yards & 0.836 & sq. meters & sq. meters & 1.196 & sq. yards \\
\hline sq. miles & 2.6 & sq. kilometers & sq. kilometers & 0.4 & sq. miles \\
\hline acres & 0.405 & hectares & hectares & 2.47 & acres \\
\hline Mass (weight) & & & Mass (weight) & & \\
\hline ounces & 28.35 & grams & grams & 0.035 & ounces \\
\hline pounds & 0.454 & kilograms & kilograms & 2.205 & pounds \\
\hline ton & 0.907 & metric ton & metric ton & 1.102 & ton \\
\hline Volume & & & Volume & & \\
\hline teaspoons & 5 & milliliters & milliliters & 0.033 & $\begin{array}{l}\text { fluid } \\
\text { ounces }\end{array}$ \\
\hline tablespoons & 15 & milliliters & liters & 2.1 & pints \\
\hline fluid ounces & 30 & milliliters & liters & 1.057 & quarts \\
\hline cups & 0.24 & liters & liters & 0.264 & gallons \\
\hline pints & 0.47 & liters & cubic meters & 35.315 & cubic feet \\
\hline quarts & 0.95 & liters & cubic meters & 1.308 & $\begin{array}{l}\text { cubic } \\
\text { yards }\end{array}$ \\
\hline gallons & 3.8 & liters & & & \\
\hline cubic feet & 0.028 & cubic meters & & & \\
\hline cubic yards & 0.765 & cubic meters & & & \\
\hline Temperature & & & Temperature & & \\
\hline Fahrenheit & $\begin{array}{l}\text { subtract } 32 \text {, } \\
\text { then multiply } \\
\text { by } 5 / 9\end{array}$ & Celsius & Celsius & $\begin{array}{l}\text { multiply by } 9 / 5 \text {, } \\
\text { then add } 32\end{array}$ & Fahrenheit \\
\hline Radioactivity & & & Radioactivity & & \\
\hline picocuries & 37 & millibecquerel & millibecquerels & 0.027 & picocuries \\
\hline
\end{tabular}




\subsection{INTRODUCTION}

This sampling and analysis instruction (SAI) describes the sample collection, handling, and analytical requirements that will be used for the in situ bioremediation pilot study for remediation of petroleum hydrocarbon-impacted soil at the UPR-100-N-17 waste site in the 100-N Area. The form of bioremediation selected for this pilot is bioventing, which consists of injection of air into the vadose zone to facilitate bioremediation by native biota. The pilot study includes installation of seven bioventing bioremediation vadose wells and conducting bioventing pilot tests. The data collected from this study will be used to evaluate the potential applicability of bioremediation to meet cleanup goals for other petroleum waste sites at 100-N and support design of a possible large-scale bioventing system. The U.S. Environmental Protection Agency (EPA) and the Washington State Department of Ecology (Ecology) have selected bioremediation as the technology for remediation of the petroleum-contaminated sites in the 100-N Area. This decision is discussed in the Interim Action Record of Decision for the 100-NR-1 and 100-NR-2 Operable Units, Hanford Site, Benton County Washington (ROD) (EPA 1999) and the Remedial Design Report/Remedial Action Work Plan for the 100-N Area (RDR/RAWP) (DOE-RL 2006b).

This section provides background information about the site contamination, a summary of the results from previous investigations, a description of the technology, and a list of the analytical parameters for data collection.

\section{$1.1 \quad$ BACKGROUND}

The 100-N Reactor operated between 1963 and 1987. Throughout the operational history of the 100-N Reactor, spills, releases, and discharges were documented in unplanned release (UPR) reports. A number of these releases have resulted in petroleum hydrocarbon contamination in the vadose zone and groundwater at 100-N. These releases occurred through mechanisms inclusive of corrosion failure of piping systems used to transport diesel and fuel oils, overfilling of storage facilities, and spills during fuel transfers.

Two of the releases, UPR-100-N-17 and UPR-100-N-42, are substantial, extending through the deep vadose zone to groundwater and, based on reports estimated during the time of operation, may have each resulted in up to $39,000 \mathrm{~m}^{3}\left(1,377,272 \mathrm{ft}^{3}\right)$ of soil contaminated with petroleum hydrocarbons. The Interim Action ROD for the 100-N Area (EPA 1999) identifies in situ bioremediation as the remedy for the two deep petroleum sites at 100-N, which have contamination at depths exceeding $4.6 \mathrm{~m}$ (15 ft) below ground surface. The UPR-100-N-17 waste site has been selected for implementation of a bioventing pilot test to evaluate the potential applicability of this technology to meet cleanup goals at 100-N waste sites affected by releases of petroleum hydrocarbons. Figure 1 shows the location of the UPR-100-N-17 waste site (labeled as UN-100-N-17). 
Figure 1. Map Showing Location of UPR-100-N-17 Waste Site.
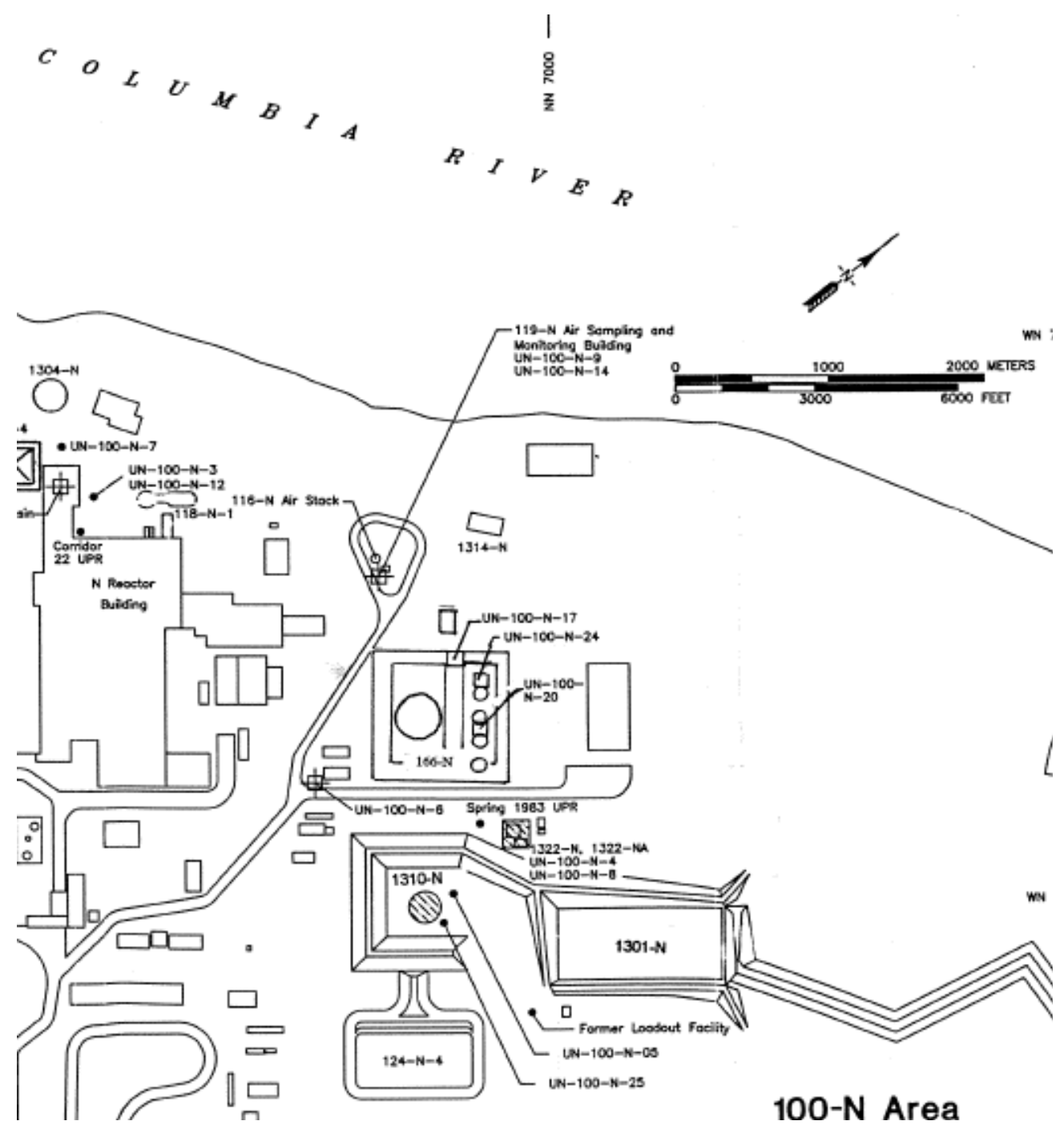

\subsubsection{UPR-100-N-17 Site Description}

The 166-N Tank Farm was an earthen-bermed tank farm that contained one aboveground 5,204,941 L (1,375,000-gal) No. 6 (Bunker C) fuel oil tank and four aboveground 397,468 L $(105,000-$ gal) diesel oil storage tanks (Figure 2). The earthen berm had a total containment capacity of $11,500,000 \mathrm{~L}(3,030,000 \mathrm{gal})$. The tank farm was located between the $116-\mathrm{N}$ air stack and the 1310- $\mathrm{N}$ radioactive chemical waste treatment and storage facility (Figure 3 ) and was in operation beginning in 1963 (WHC 1994). The 166-N Facility was used to deliver and store fuel oil and diesel for the 105-N Reactor Building, with a direct feed to the 184-N Power House and ancillary facilities. 
Figure 2. Photograph of 166-N Tank Farm Facility (early 1960's).

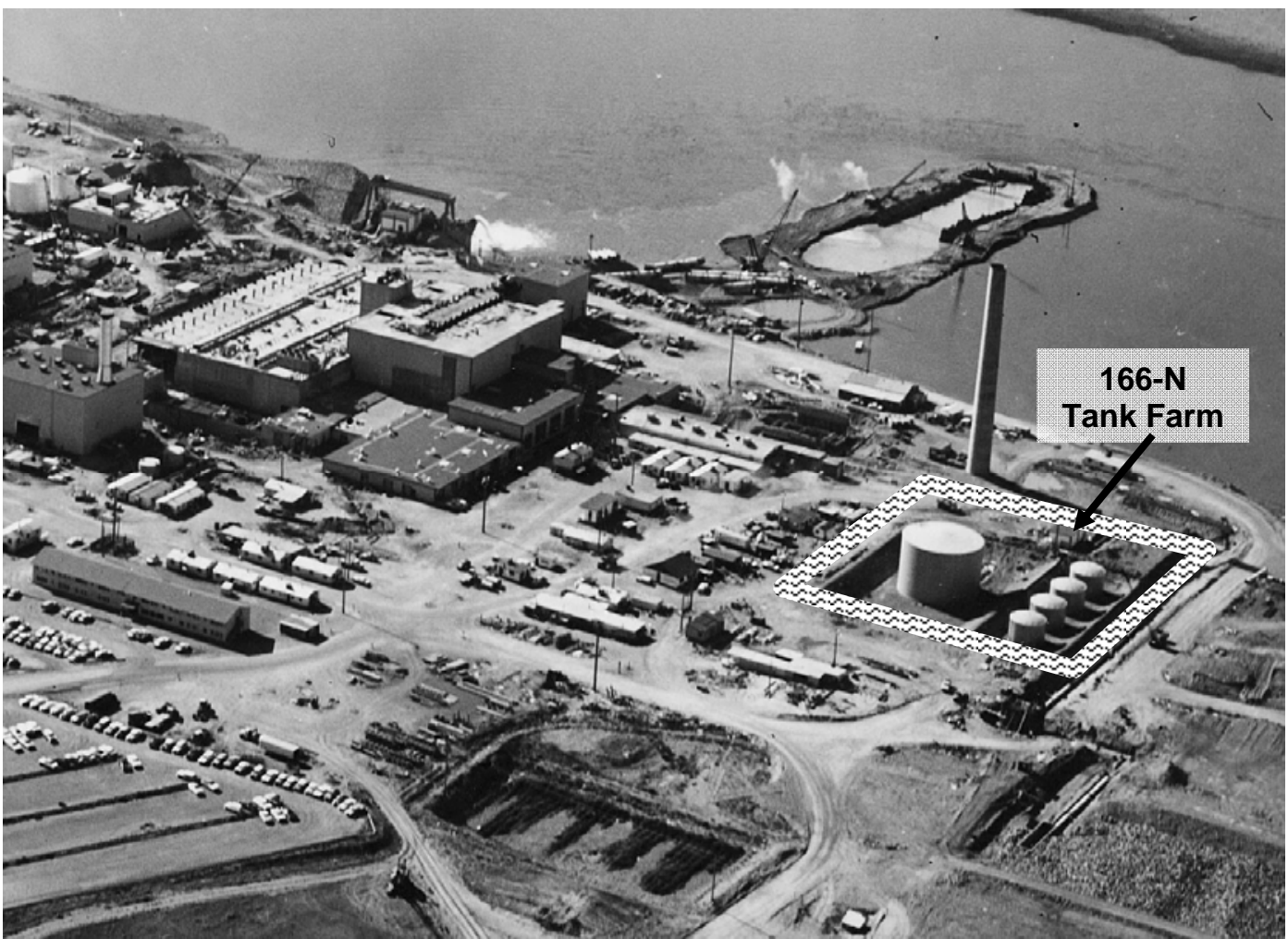

Figure 3. Photograph of 166-N Tank Farm Facility.

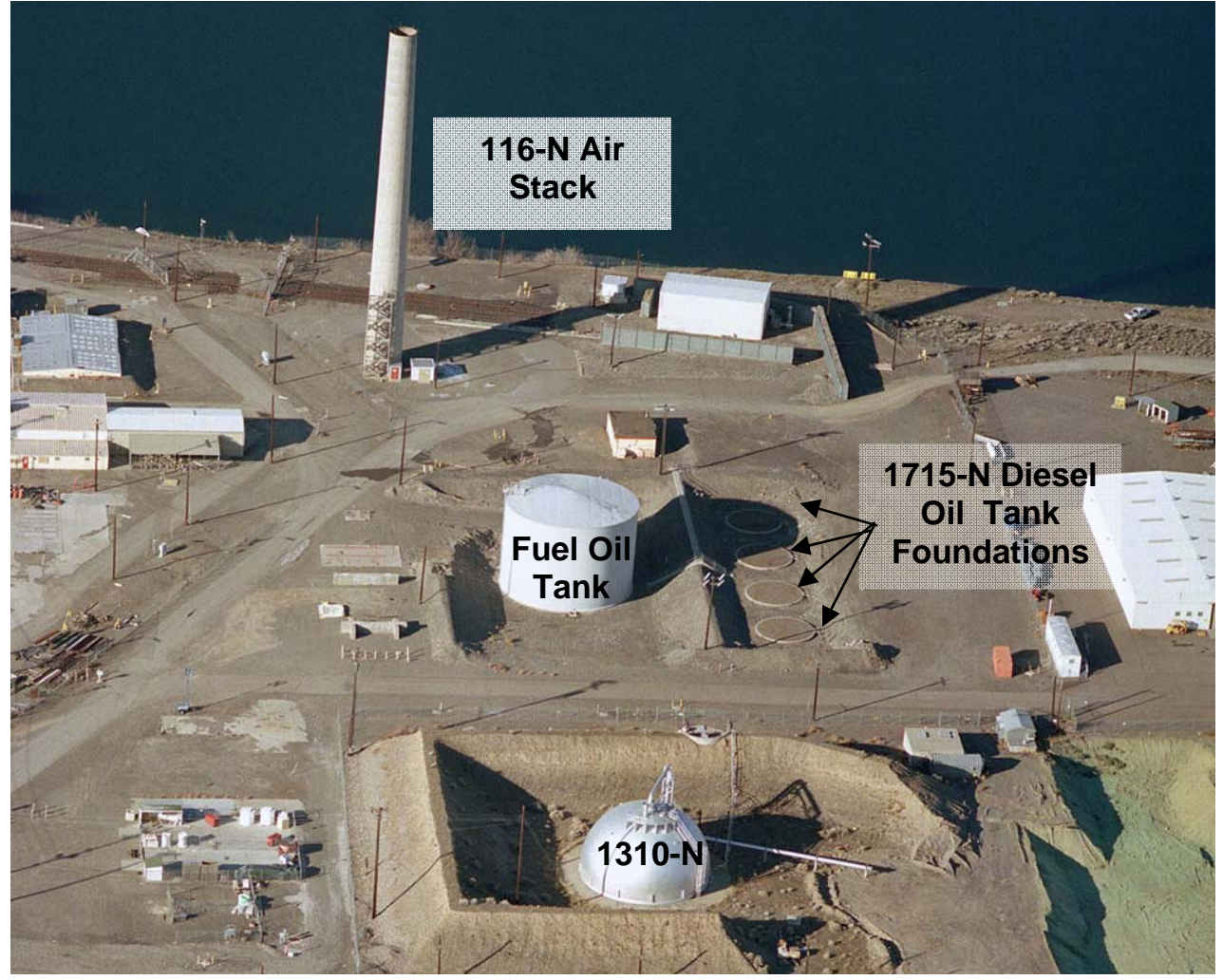

Sampling and Analysis Instruction for Installation of UPR-100-N-17 Bioremediation Wells and Performance of Bioventing Pilot Tests 
In August 1966, an estimated 301,832 L (80,000 gal) of diesel oil leaked from an oil transfer line near the 166- $\mathrm{N}$ facility. This release is identified in the Hanford Waste Information Database System (WIDS) as UPR-100-N-17. The line was excavated and repaired in September 1966. Oil near the river was collected in a trench (100-N-65) that had been excavated along the riverbank in an attempt to intercept the oil before it could reach the river (GE 1967). Oil in the trench was ignited and burned off periodically through 1967.

Demolition of the 166-N facilities included removal of the fuel oil tank in January 2006 and removal of the 166-N Pump House and the 166-N Unloading Station in April 2006 (WCH 2006). The four 1715-N diesel tanks were removed approximately 10 years prior during demolition work, leaving the tank foundations to be removed during the 2006 demolition. Figure 3 is a photograph showing the 166-N Tank Farm after removal of the four diesel storage tanks and prior to the 2006 demolition activities.

\subsubsection{Site Hydrogeology}

The hydrogeology of the 100-N Area is discussed in Hydrogeology of the 100-N Area, Hanford Site, Washington (Hartman and Lindsey 1993). The stratigraphic units of significance underlying the 100-N Area include the Hanford formation, the Ringold Formation, and the Elephant Mountain Member of the Saddle Mountains Basalt. The Hanford formation overlies the Ringold Formation and consists of two gravel-dominated facies: an upper cobble-boulder unit and a lower pebblecobble unit. The Ringold Formation overlies the Elephant Mountain Member and consists of seven units. Thickness of the Hanford formation and Ringold Formation ranges from 5.8 to 24.5 $\mathrm{m}$ (19 to $77 \mathrm{ft}$ ) and 137.2 to $150.6 \mathrm{~m}$ (450 to $494 \mathrm{ft}$ ), respectively.

1.1.2.1 Geology. Extensive grading, excavation, and backfilling of the surficial Hanford formation have occurred within and around the 166-N waste site because of decommissioning and site remediation activities. Consequently, it can be difficult to distinguish undisturbed Hanford formation from anthropogenically disturbed Hanford formation because of similar bulk composition.

The upper portion of the Hanford formation is composed of unconsolidated basaltic cobble and

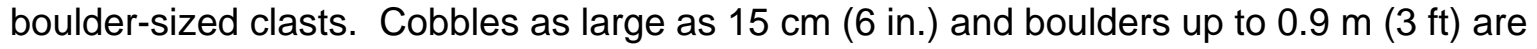
present at 100-N Area. Below the cobble-boulder unit, clast size decreases to pebbles and cobbles with local dominant sand. The gravel and sand are predominantly basaltic in composition. Significant sand layers are sometimes intercepted during drilling. In the vadose zone, sand layers may promote localized lateral spread of contamination. Characterization boreholes drilled near the 1301-N and 1325-N waste sites have noted that these sand zones are discontinuous and cannot be traced with certainty between wells (DOE-RL 1996b). For most of the 100-N Area, the Hanford formation extends from ground surface to just above the water table, 5.8 to $24.5 \mathrm{~m}$ (19 to $77 \mathrm{ft}$ ) in thickness. However, channels of Hanford gravels extending below the water table occur.

The underlying Ringold Formation consists of a mix of fluvial gravels, fluvial sands, overbank deposits, paleosols, and lake deposits and unconformably overlies the Saddle Mountain Basalt in the 100-N Area. The Ringold has been subdivided into three informal geologic units in the 100-N Area (Figure 4). These are, in ascending order, Ringold unit 3, Ringold unit 2, and Ringold unit 1. Ringold unit 2 has been divided into three subunits, which have been differentiated based on vertical lithologies and depositional environments. Hartman and Lindsey (1993) describe the Ringold Formation in the 100-N Area using five Ringold stratigraphic subdivisions (Figure 5).

Sampling and Analysis Instruction for Installation of UPR-100-N-17 Bioremediation Wells and Performance of Bioventing Pilot Tests 
Figure 4. Hydrogeologic Units Beneath 100-N Area (from DOE-RL 1996c).

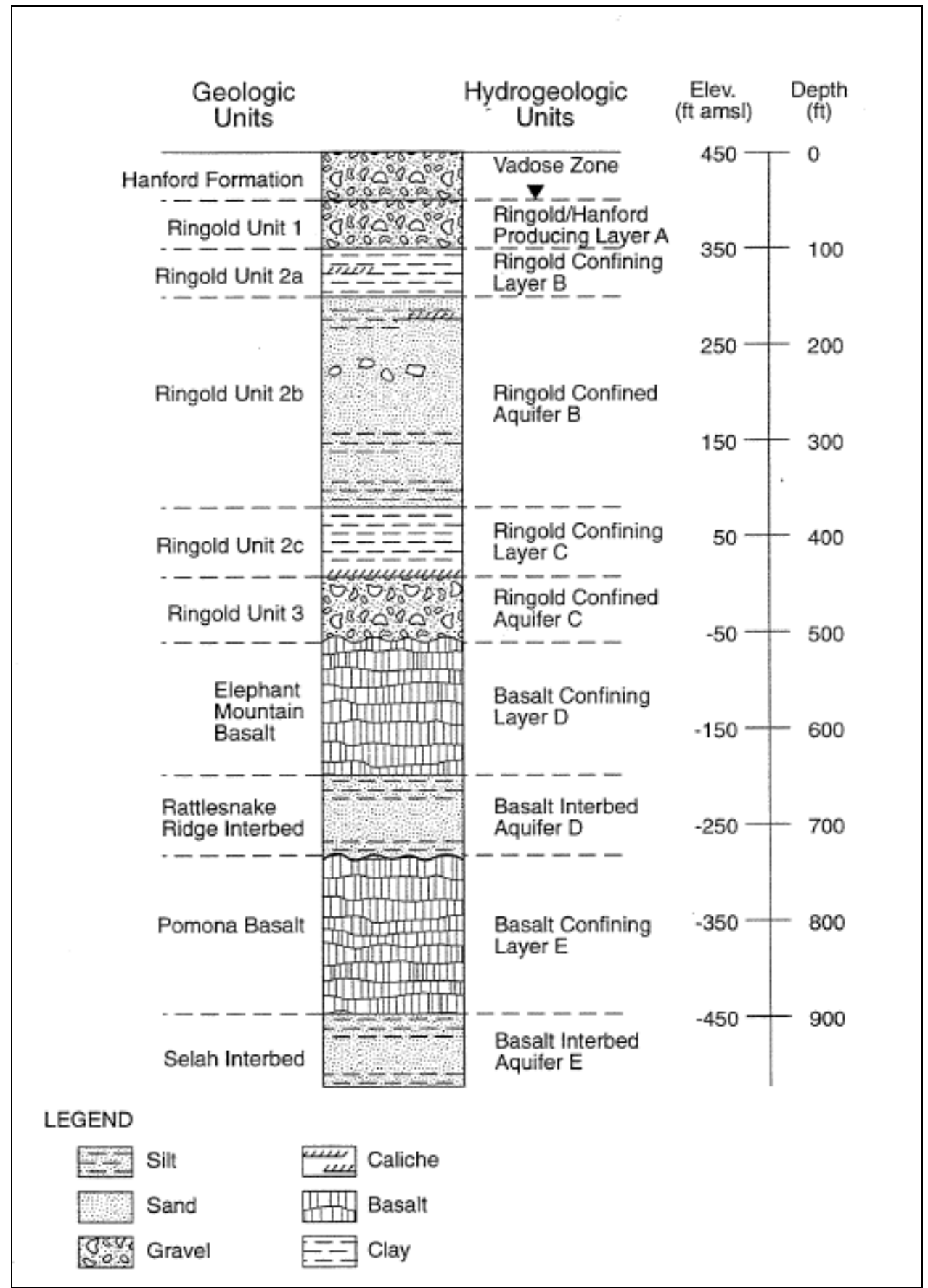


Figure 5. Hydrogeologic Units Beneath 100-N Area (from Hartman and Lindsey 1993).

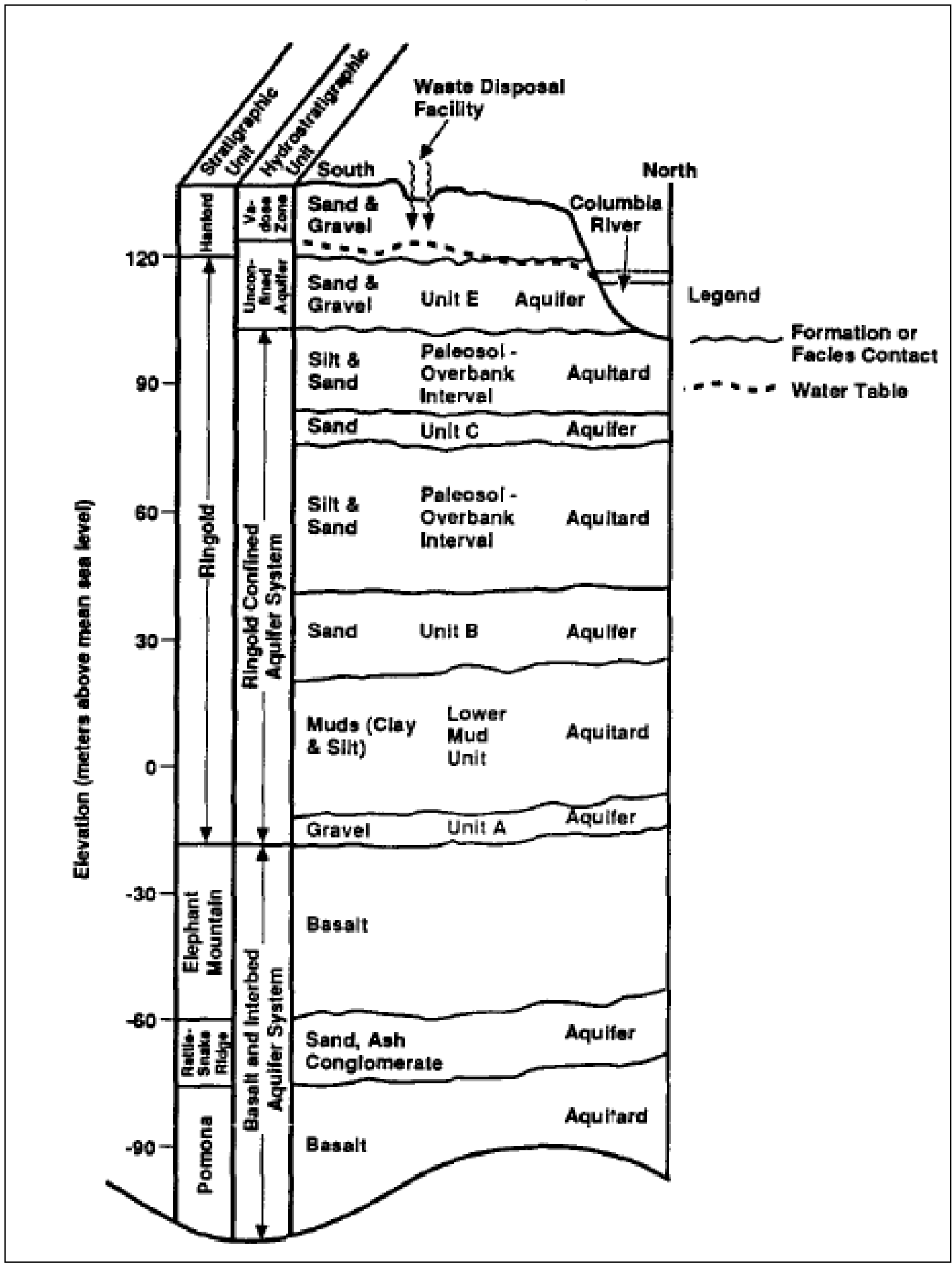

Sampling and Analysis Instruction for Installation of UPR-100-N-17 Bioremediation Wells and Performance of Bioventing Pilot Tests 
These are in ascending order, unit A through unit $\mathrm{E}$. The uppermost Ringold stratum at $100-\mathrm{N}$ is unit $\mathrm{E}$, consisting of variably cemented pebble to cobble gravel with a fine- to coarse-grained sand matrix. Sand and silt interbeds also may be present. Unit E exhibits a more felsic (quartzitic) composition that the underlying Ringold subunits and can be differentiated from the overlying Hanford formation based on the composition of the sand. Ringold unit $E$ has tan sands derived from primarily metamorphic rocks, while the Hanford formation has black sands derived primarily from basalt. In addition, the Ringold unit $E$ is more compact that the Hanford formation. The contact between the Hanford formation and the Ringold Formation is sometimes difficult to determine because a transition zone of reworked Ringold Formation is often present. Unit $\mathrm{E}$ forms the unconfined aquifer in the 100-N Area and is approximately 12 to $15 \mathrm{~m}$ (39 to $49 \mathrm{ft}$ ) thick. The base of the aquifer is situated at the contact between the Ringold Unit $E$ and the underlying, much less transmissive, silty strata referred to locally as the Ringold Upper Mud, approximately

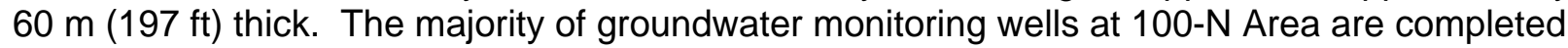
within the Ringold unit E.

1.1.2.2 Hydrology. The 100-N Area is underlain by an unconfined aquifer, a series of confined aquifers in the unconsolidated sediments, and a series of confined aquifers in the basalts and interbeds. The uppermost aquifer beneath the 100-N Area is an unconfined sand and gravel unit in the Ringold Formation (Ringold unit E) and is approximately 12 to $15 \mathrm{~m}$ (40 to $50 \mathrm{ft}$ ) thick. The unconfined aquifer at $100-\mathrm{N}$ Area both before and after operations is relatively flat with an average gradient of $0.001 \mathrm{~m} / \mathrm{m}(0.003 \mathrm{ft} / \mathrm{ft})$ toward the northwest where it is bounded by the Columbia River. The water table in this area is dominated by the Columbia River water level stages. The use of the Priest Rapids Dam as a power facility causes the Columbia River's water

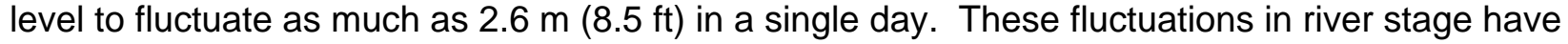
been observed to influence water levels in wells located close to the Columbia River. During high river stage, the river level may be higher than the groundwater levels in wells, initiating a temporary reversal of hydraulic gradient and the flow of river water into the unconfined aquifer.

Large volumes of water discharged during 100-N operations (1964-1989) caused the water table to rise beneath the 1301-N and 1325-N waste disposal facilities (DOE-RL 1996b). The water

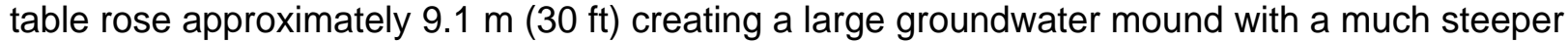
groundwater gradient $(0.02$ to $0.05 \mathrm{~m} / \mathrm{m}$ [0.07 to $0.16 \mathrm{ft} / \mathrm{ft}]$ ) toward the Columbia River. During operations, this mound became the dominant feature of the unconfined aquifer and in locations, the bottom portion of the Hanford formation was saturated from groundwater mounding. The depth to groundwater at the 166-N Facility is approximately $22 \mathrm{~m} \mathrm{(72} \mathrm{ft)} \mathrm{and} \mathrm{may} \mathrm{show} \mathrm{a} \mathrm{wide}$ seasonal range in elevation due to fluctuating Columbia River water level stages.

1.1.2.3 Physical Properties of the Vadose Zone. The vadose zone beneath the 100-N Area comprises primarily the unconsolidated sediments of the Hanford formation. In some locations, the top few feet of the Ringold Formation are also present in the vadose zone. The unsaturated Ringold sediments are similar to the Hanford formation and consist of sands, gravels, and cobbles, with varying fractions of silt. The vadose zone is 20 to $23 \mathrm{~m} \mathrm{(65} \mathrm{to} 75 \mathrm{ft}$ ) thick beneath most of the 100-N Area.

The water content at depth in vadose sediments at the Hanford Site is low generally, ranging from $2 \%$ to $7 \%$ in coarse and medium-grained soils and $7 \%$ to $15 \%$ in silts. Volumetric moisture content of the coarse-grained geologic units collected during borehole drilling near the 1301-N and $1325-\mathrm{N}$ waste sites varied from 5 to 13 volume percent for laboratory measured moisture content and from 9 to 10 volume percent as determined using down hole geophysical surveys

Sampling and Analysis Instruction for Installation of UPR-100-N-17 Bioremediation Wells and Performance of Bioventing Pilot Tests 
(DOE-RL 1996b). Finer grained sands and silt retained more moisture with 9 to 16 volume percent for the laboratory measurements and 15 to 20 volume percent for the in situ geophysical measurements. Dry bulk density ranged from 1.76 to $2.2 \mathrm{~g} / \mathrm{cm}^{3}$ and porosity from $24 \%$ to $35 \%$. Saturated hydraulic conductivity measurements ranged from 0.01 to $54 \mathrm{~m} /$ day (0.03 to $177 \mathrm{ft} /$ day).

\subsubsection{Previous Investigations}

Releases at the 166-N Tank Farm were evaluated as part of a limited field investigation for the 100-NR-1 Operable Unit (DOE-RL 1995). A soil gas survey consisting of a series of probes

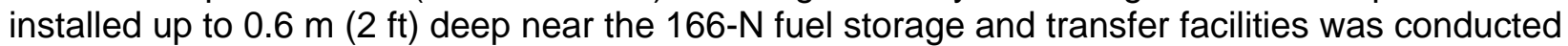
in 1992 to determine the presence of surface and subsurface volatile organic compounds (VOCs) and petrochemicals. None of the VOCs (i.e., benzene, ethylbenzene, toluene, and xylenes [BTEX]) typically associated with fuel products were detected in any of the soil gas samples. However, methane and depleted oxygen levels were measured that indicated evidence of petroleum biodegradation. Soil cuttings removed during installation of the probes were field tested and found to contain elevated levels of total petroleum hydrocarbons (TPH). Trace concentrations of perchloroethylene (PCE), a fuel additive, were detected in areas where Number 6 fuel oil was unloaded or transferred.

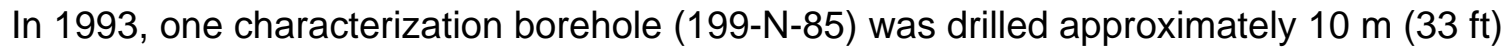
southeast of the UPR-100-N-17 waste site to a total depth of $23 \mathrm{~m}(75 \mathrm{ft})$. Groundwater was encountered at $22 \mathrm{~m}$ (72.5 ft). Ten split-spoon soil samples were collected and submitted for chemical and radionuclide analysis. Concentrations of acetone, benzene, ethylbenzene, and xylene were detected in soils at depths between 20 and $22 \mathrm{ft}$ (65 and $71 \mathrm{ft}$ ). Unfortunately, TPH was not analyzed in soil samples. During the drilling, field screening for organics, combustible gas, and percent oxygen was performed. When the borehole reached approximately $16 \mathrm{~m}$ (51 ft),

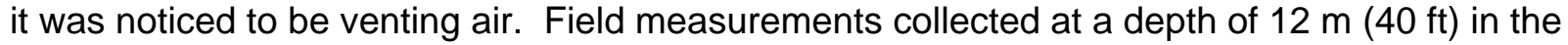
borehole indicated over $100 \%$ lower explosive limit (LEL) combustible gas and 11\% oxygen, with a flame ionization detector (FID) indicating $1000 \mathrm{ppm}$. An air sample was collected for laboratory analysis with results indicating $3.4 \%$ methane, $6.5 \%$ carbon dioxide, and $11 \%$ oxygen.

Petroleum hydrocarbons from historical releases continue to be detected in $100-\mathrm{N}$ groundwater (DOE-RL 2008). Of the affected wells, 199-N-18 is closest to the UPR-100-N-17 site and had the highest levels of contamination detected during fiscal year (FY) 2007 groundwater monitoring. In September 2007, the well had $190 \mathrm{mg} / \mathrm{L} \mathrm{TPH}$ in the diesel range. Peak concentrations of thousands of milligrams per liter were observed between 2001 and 2003. A passive remedial method to remove free product from well 199-N-18 has been performed and continued in FY 2007. The method employs a polymer that selectively absorbs petroleum products from the surface of the water like a sponge. Four cylinders of this material are lowered into the well, where the material absorbs the contamination. The cylinders are changed every 2 months when they are saturated with oil.

\subsection{TECHNOLOGY DESCRIPTION}

Bioremediation is the use of microorganisms to degrade contaminants with the goal of obtaining nonhazardous final products. The microorganisms produce natural catalysts (enzymes) that degrade organic compounds forming carbon dioxide $\left(\mathrm{CO}_{2}\right)$, methane $\left(\mathrm{CH}_{4}\right)$, water, and mineral salts. Enhanced bioremediation involves the introduction of nutrients (typically nitrogen and

Sampling and Analysis Instruction for Installation of UPR-100-N-17 Bioremediation Wells and Performance of Bioventing Pilot Tests

December 2008 
phosphate) and electron donors or acceptors (oxygen) to enhance the biodegradation provided by the naturally occurring microbes indigenous to the site. Frequently, water is also introduced to the subsurface to bring soil moisture content into the optimum range for bioremediation. Upon the introduction of air, nutrients, and, if necessary, water into the subsurface, the population of indigenous microbes thrives and uses the petroleum hydrocarbons as its food source ${ }^{1}$. The result is that the hydrocarbons are degraded aerobically, or oxidized, to carbon dioxide and water.

\subsubsection{Bioventing}

Bioventing is an in situ soil remediation technology that stimulates indigenous soil bacteria to degrade organic compounds adsorbed to soils in the unsaturated zone through the introduction of oxygen. Soil typically contains bacteria, including hydrocarbon-degrading aerobic bacteria, which use oxygen to metabolize organic compounds, producing carbon dioxide and water - a process known as aerobic respiration. When hydrocarbons and sufficient oxygen exist in soil, microorganisms metabolize, grow, and multiply rapidly until oxygen depletion slows or stops the metabolic process. If the oxygen concentration is not replenished, microbial respiration and population growth slows. Bioventing introduces additional oxygen into the open pore spaces of vadose soil, keeping aerobic respiration going and, thus, promoting the microbial destruction of the hydrocarbon food source. Bioventing has been widely applied and proven effective in remediating releases of petroleum products including gasoline, diesel, and BTEX compounds.

\subsection{BIOVENTING PILOT TEST OBJECTIVES}

A pilot test at the UPR-100-N-17 waste site is being performed to evaluate the use of in situ bioremediation, in particular, bioventing as a soil remediation technology. The objectives of the test include the following:

- Providing data to evaluate effectiveness of bioventing to meet cleanup goals for petroleum hydrocarbons at 100- $\mathrm{N}$ waste sites

- Determine if contaminated soil volume is anaerobic and in need of oxygen to stimulate biodegradation

- Determine if the contaminated soil volume has adequate permeability to promote uniform oxygen distribution via air injection

- Confirm that the soil contains petroleum-degrading microorganisms and establish the initial rates of biodegradation that can be expected for the site.

\subsubsection{Bioventing Well Installation}

A network of seven vadose zone wells will be installed for the pilot bioventing system. The bioventing wells will be installed using cable tool drilling techniques in accordance with Washington Administrative Code (WAC) 173-160, "Minimum Standards for Construction and Maintenance of Wells." Alternative drilling methods may be used, but must be approved by the Washington Closure Hanford (WCH) Project Lead. The pilot test design will evaluate bioventing

\footnotetext{
${ }^{1}$ The addition of water to the vadose zone is currently not anticipated for the application of this technology at the UPR-100-N-17 waste site.
}

Sampling and Analysis Instruction for Installation of UPR-100-N-17 Bioremediation Wells and Performance of Bioventing Pilot Tests 
for both shallow and deep vadose zone soil. One shallow injection well (SIW) and one shallow

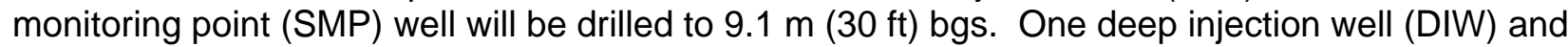
four deep monitoring point (DMP) wells will be drilled to just below the water table (approximately

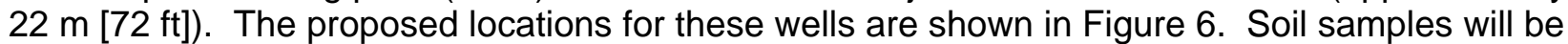
collected during drilling and will be analyzed for those parameters that are needed to support evaluation of the bioventing technology for petroleum hydrocarbon remediation. Requirements for soil sampling and analysis during well drilling are described in Section 3.1.

\subsubsection{Bioventing Pilot Tests}

Bioventing pilot tests will be conducted to evaluate contaminant removal rates and the distribution of airflow within the contaminated zone. The tests will consist of soil gas measurements, respirometry tests, and air injection tests. Soil gas monitoring is performed to determine the baseline concentrations of oxygen, carbon dioxide, and volatile hydrocarbons. Air injection tests will be performed to evaluate soil permeability and supply of adequate oxygen to the contaminated soil. The respirometry tests are performed to provide estimates of in situ biodegradation rates. These tests are further described in Section 3.2.

\subsubsection{Data Requirements for Bioventing Pilot Test}

Although much is known about the hydrogeologic conditions of the vadose zone in the 100-N Area, some of the physical and chemical parameters important to successful implementation of bioremediation and bioventing are not available and will need to be collected during well installation and performance of pilot tests. Specifically, data concerning the concentrations of indigenous bacteria and nutrients in the subsurface and quantitative site-specific data concerning the nature and extent of petroleum contamination are needed. Table 1 provides a summary of the data that will be collected during well installation and during performance of pilot tests. 


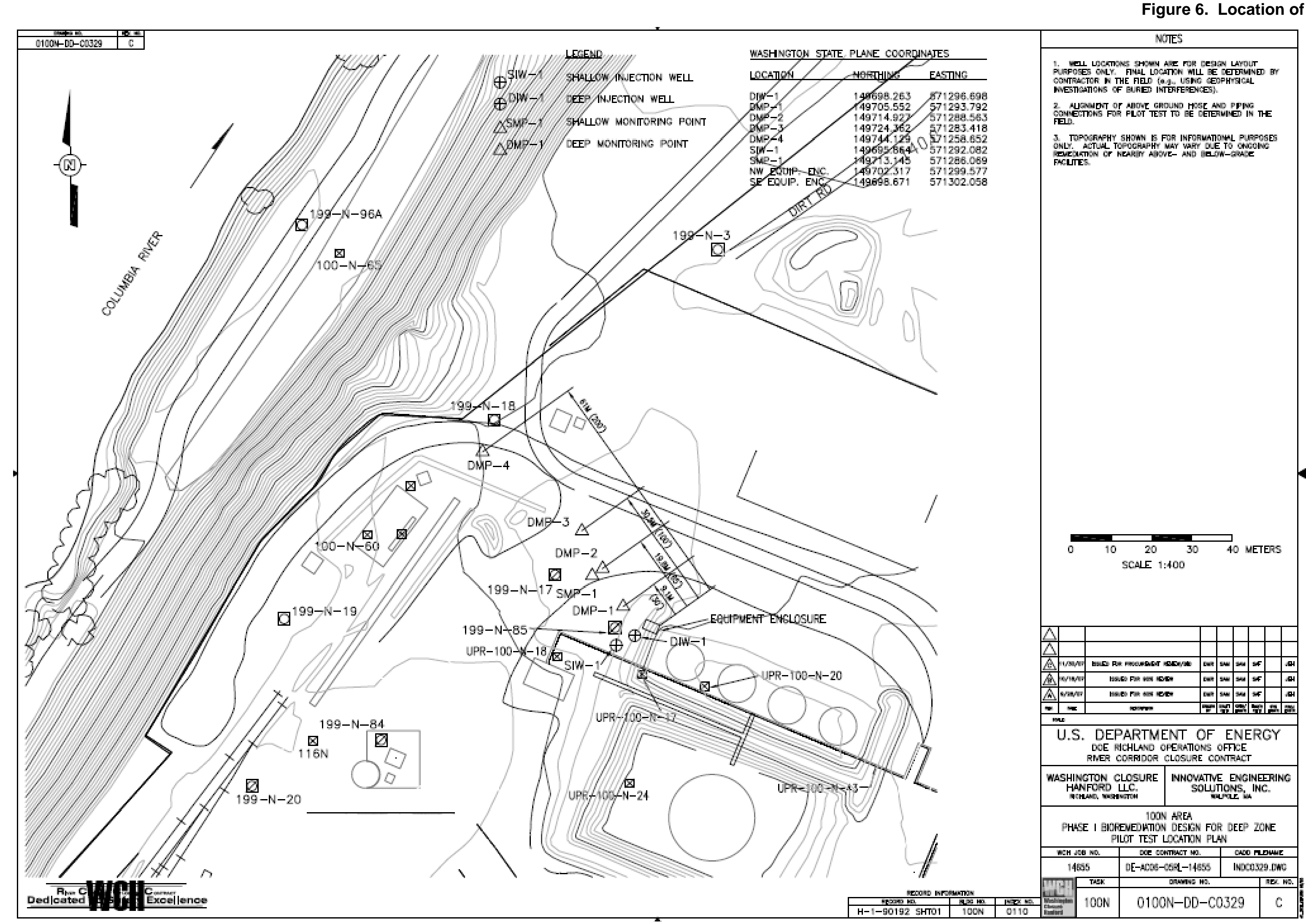


Table 1. Characterization Parameters for Bioremediation/Bioventing.

\begin{tabular}{|c|c|c|}
\hline Parameter & Purpose & Methodology \\
\hline TPH-diesel & $\begin{array}{l}\text { Determine concentration of target constituent } \\
\text { and toxicity to microbial population. }\end{array}$ & Collect soil samples during well drilling. \\
\hline TPH-gasoline & $\begin{array}{l}\text { Determine concentration of target constituent } \\
\text { and toxicity to microbial population. }\end{array}$ & Collect soil samples during well drilling. \\
\hline TPH-motor oil & $\begin{array}{l}\text { Determine concentration of target constituent } \\
\text { and toxicity to microbial population. }\end{array}$ & Collect soil samples during well drilling. \\
\hline Oil and grease & $\begin{array}{l}\text { Determine concentration of target constituent } \\
\text { and toxicity to microbial population. }\end{array}$ & Collect soil samples during well drilling. \\
\hline Total nitrogen & Determine mineral nutrient requirements. & Collect soil samples during well drilling. \\
\hline Orthophosphate & Determine mineral nutrient requirements. & Collect soil samples during well drilling. \\
\hline VOCs & $\begin{array}{l}\text { Determine concentration of benzene, toluene, } \\
\text { ethylbenzene, and xylenes }\end{array}$ & Collect soil samples during well drilling. \\
\hline Total organic carbon & $\begin{array}{l}\text { Determine presence of organic matter and } \\
\text { adsorption characteristics of soil. }\end{array}$ & Collect soil samples during well drilling. \\
\hline RCRA metals & $\begin{array}{l}\text { Identify contaminants that may inhibit microbial } \\
\text { metabolism. }\end{array}$ & Collect soil samples during well drilling. \\
\hline $\begin{array}{l}\text { Hexavalent } \\
\text { chromium }\end{array}$ & Evaluate hexavalent chromium in vadose zone. & Collect soil samples during well drilling. \\
\hline Strontium-90 & $\begin{array}{l}\text { Determine if strontium- } 90 \text { has been introduced } \\
\text { into the deep vadose soil from historical } \\
\text { fluctuations of the groundwater table. }\end{array}$ & Collect soil samples during well drilling. \\
\hline $\begin{array}{l}\text { Heterotrophic } \\
\text { bacterial plate count }\end{array}$ & $\begin{array}{l}\text { Determine indigenous/adapted microbial } \\
\text { population densities in soil. }\end{array}$ & Collect soil samples during well drilling. \\
\hline $\mathrm{pH}$ & Verify pH suitable for microbial metabolism. & Collect soil samples during well drilling. \\
\hline Moisture content & $\begin{array}{l}\text { Determine conditions suitable for microbial } \\
\text { metabolism; influences air permeability. }\end{array}$ & $\begin{array}{l}\text { Collect soil samples during well drilling; } \\
\text { perform geophysical logging. }\end{array}$ \\
\hline $\begin{array}{l}\text { Depth to } \\
\text { groundwater }\end{array}$ & $\begin{array}{l}\text { Determine depth to set well screen for deep } \\
\text { vadose wells. }\end{array}$ & $\begin{array}{l}\text { Measure depth to groundwater for deep } \\
\text { vadose wells. }\end{array}$ \\
\hline Permeability & $\begin{array}{l}\text { Determine ability to deliver oxygen to the } \\
\text { contaminated zone. }\end{array}$ & $\begin{array}{l}\text { Calculated from air injection tests; } \\
\text { supplemented with existing data for } \\
\text { hydraulic conductivity, bulk density, } \\
\text { grain-size distribution; and porosity. }\end{array}$ \\
\hline $\begin{array}{l}\mathrm{O}_{2} \text { content in soil } \\
\text { gas }\end{array}$ & Evaluate biodegradation rates. & $\begin{array}{l}\text { Field measurements during drilling and } \\
\text { during pilot tests. }\end{array}$ \\
\hline $\begin{array}{l}\mathrm{CO}_{2} \text { content in soil } \\
\text { gas }\end{array}$ & Evaluate biodegradation rates. & $\begin{array}{l}\text { Field measurements during drilling and } \\
\text { during pilot tests. }\end{array}$ \\
\hline VOC in soil gas & Evaluate biodegradation rates. & $\begin{array}{l}\text { Field measurements during drilling and } \\
\text { during pilot tests. }\end{array}$ \\
\hline $\begin{array}{l}\text { Pressure } \\
\text { measurements }\end{array}$ & $\begin{array}{l}\text { Evaluate radius of influence of oxygen injection } \\
\text { in vadose zone. }\end{array}$ & $\begin{array}{l}\text { Pressure measurements collected during } \\
\text { pilot tests. }\end{array}$ \\
\hline
\end{tabular}

$\mathrm{TPH}=$ total petroleum

VOC = volatile organic compound

RCRA = Resource Conservation and Recovery Act of 1976

Sampling and Analysis Instruction for Installation of UPR-100-N-17 Bioremediation Wells and Performance of Bioventing Pilot Tests

December 2008 


\subsection{PROJECT MANAGEMENT}

This section identifies the individuals or organizations participating in the project and discusses specific roles and responsibilities of the individuals/organizations. The quality objectives for measurement data and the special training requirements for the staff performing the work are also discussed.

Sampling and analysis activities will be performed in accordance with the following requirements:

- DOE 414.1A, Quality Assurance

- EPA Requirements for Quality Assurance Project Plans for Environmental Data Operations (EPA 2001)

- Hanford Analytical Services Quality Assurance Requirements Documents (DOE-RL 1996a).

The sampling and analysis requirements specified in this SAI are consistent with the quality assurance (QA) and quality control (QC) requirements specified in 100-N Area Sampling and Analysis Plan for CERCLA Waste Sites (DOE-RL 2006a).

\subsection{PROJECT/TASK ORGANIZATION}

WCH has overall responsibility for the bioremediation pilot study. The project management organization is depicted in Figure 7.

\subsection{QUALITY OBJECTIVES AND CRITERIA FOR MEASUREMENT DATA}

The required detection limits and the precision and accuracy requirements for the laboratory and field screening measurements are discussed in this section.

\subsubsection{Laboratory Measurements}

Laboratory-specific standard operating procedures (SOPs) for the analytical methods are established in contracted laboratory QA plans. Table 2 provides a list of the analytical methods for laboratory analysis of soil samples.

Sampling and Analysis Instruction for Installation of UPR-100-N-17 Bioremediation Wells and Performance of Bioventing Pilot Tests

December 2008 
Figure 7. Project Organization.

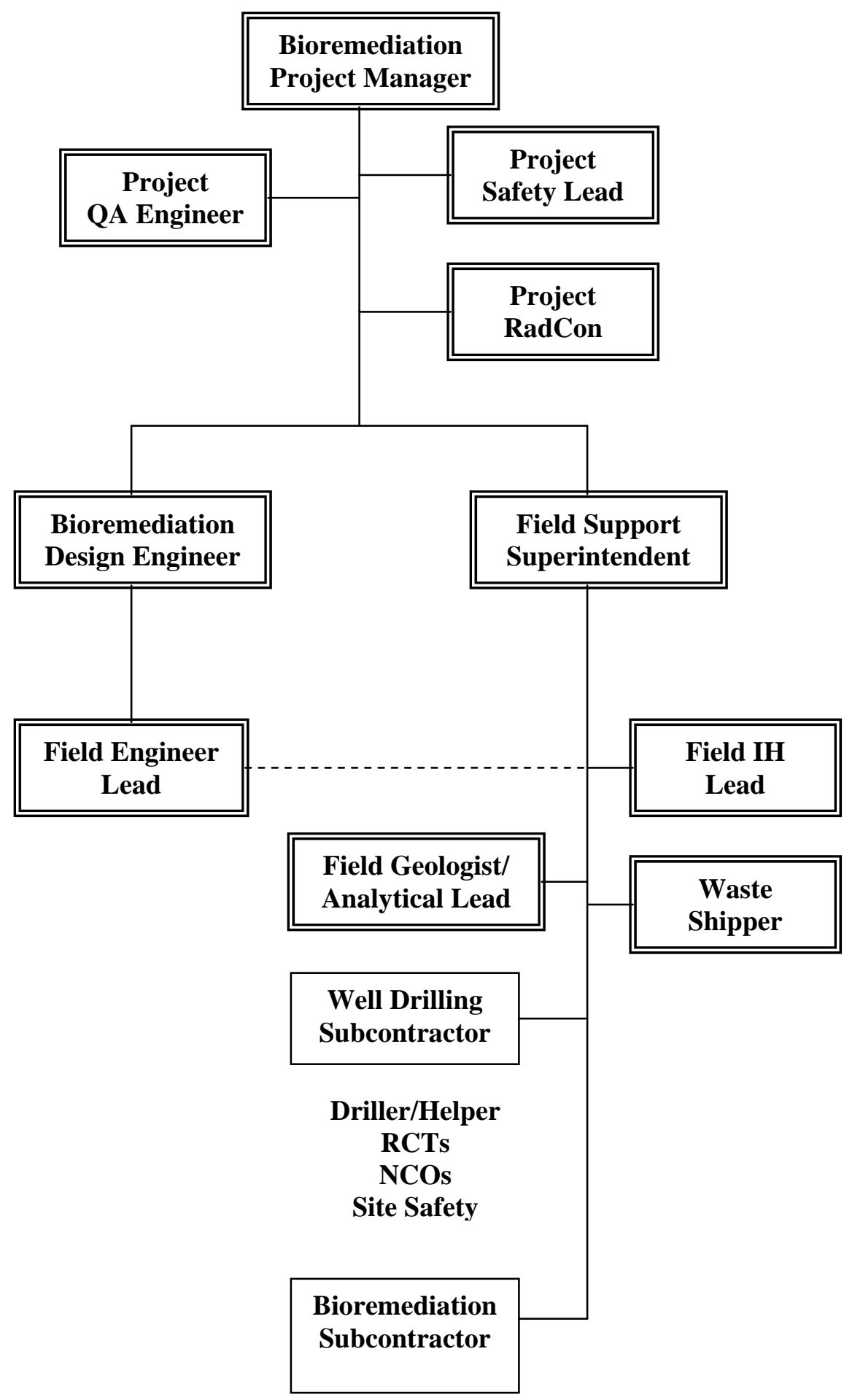


Table 2. Analytical Performance Requirements - Laboratory.

\begin{tabular}{|c|c|c|c|c|}
\hline Analytical Method & Analyte & $\begin{array}{c}\text { RDL } \\
\text { Requirement }\end{array}$ & $\begin{array}{c}\text { Accuracy } \\
\text { (\% Recovery) }\end{array}$ & $\begin{array}{l}\text { Precision } \\
\text { (\% RPD) }\end{array}$ \\
\hline $\begin{array}{l}\text { TPH - Gasoline Range } \\
\text { (WTPH-G) }\end{array}$ & Gasoline & $5.0 \mathrm{mg} / \mathrm{kg}$ & $50-150$ & \pm 30 \\
\hline $\begin{array}{l}\text { TPH - Diesel Range } \\
\text { (WTPH-D) }\end{array}$ & Diesel oil & $5.0 \mathrm{mg} / \mathrm{kg}$ & $50-150$ & \pm 30 \\
\hline $\begin{array}{l}\text { TPH - Motor Oil Range } \\
\text { (WTPH - Dx) }\end{array}$ & Motor oil & $5 \mathrm{mg} / \mathrm{kg}$ & $50-150$ & \pm 30 \\
\hline EPA Method 9070 & Oil and grease & $100 \mathrm{mg} / \mathrm{kg}$ & $70-130$ & \pm 30 \\
\hline EPA Method 8260 & BTEX & $0.01 \mathrm{mg} / \mathrm{kg}^{\mathrm{a}}$ & $70-130$ & \pm 30 \\
\hline \multirow{7}{*}{$\begin{array}{c}\text { EPA Method } 6010 \\
\text { (trace) }\end{array}$} & Arsenic & $10 \mathrm{mg} / \mathrm{kg}$ & $70-130$ & \pm 30 \\
\hline & Barium & $2 \mathrm{mg} / \mathrm{kg}$ & $70-130$ & \pm 30 \\
\hline & Cadmium & 0.5 & $70-130$ & \pm 30 \\
\hline & Chromium & $1 \mathrm{mg} / \mathrm{kg}$ & $70-130$ & \pm 30 \\
\hline & Lead & $5 \mathrm{mg} / \mathrm{kg}$ & $70-130$ & \pm 30 \\
\hline & Selenium & $1 \mathrm{mg} / \mathrm{kg}$ & $70-130$ & \pm 30 \\
\hline & Silver & $0.2 \mathrm{mg} / \mathrm{kg}$ & $70-130$ & \pm 30 \\
\hline EPA Method 7196 & Hexavalent chromium & 0.5 & $70-130$ & \pm 30 \\
\hline $\begin{array}{l}\text { Strontium-90 } \\
\text { Liquid scintillation }\end{array}$ & Strontium-90 & $1.0 \mathrm{pCi} / \mathrm{g}$ & $70-130$ & \pm 30 \\
\hline EPA Method 9060 & Total organic carbon & $25 \mathrm{mg} / \mathrm{kg}$ & $70-130$ & \pm 30 \\
\hline ASTM D2216 & Moisture content & $0.50 \%$ & NA & NA \\
\hline SM 9215. $D^{b}$ & $\begin{array}{l}\text { Heterotrophic bacterial plate } \\
\text { count }\end{array}$ & $\mathrm{CFU} / \mathrm{g}$ & NA & NA \\
\hline EPA Method 351.N & $\begin{array}{l}\text { Total Kjeldahl Nitrogen } \\
(\mathrm{TKN})\end{array}$ & $2.5 \mathrm{mg} / \mathrm{kg}$ & $70-130$ & \pm 30 \\
\hline EPA Method 350.1 & $\mathrm{NH}_{3}-\mathrm{N}$ Nitrogen in Ammonia & $0.5 \mathrm{mg} / \mathrm{kg}$ & $70-130$ & \pm 30 \\
\hline EPA Method 300.0 & Anions, $\mathrm{NO}_{2}, \mathrm{NO}_{3}, \mathrm{P}_{3} \mathrm{O}_{4}$ & $\begin{array}{c}2.5 \mathrm{mg} / \mathrm{kg} \\
\left(\mathrm{NO}_{2} / \mathrm{NO}_{3}\right) \\
5 \mathrm{mg} / \mathrm{kg} \\
\left(\mathrm{P}_{3} \mathrm{O}_{4}\right)\end{array}$ & $70-130$ & \pm 30 \\
\hline EPA Method 9045 & Corrosivity $(\mathrm{pH})$ & $0.1 \mathrm{pH}$ unit & $70-130$ & \pm 30 \\
\hline $\begin{array}{ll}\text { CFU/g } & =\text { colony forming } \\
\text { NA } & =\text { not applicable } \\
\text { RDL } & =\text { required detecti }\end{array}$ & $\begin{array}{l}\text { nits per gram soil } \\
n \text { limit }\end{array}$ & $\begin{array}{l}=\text { relative perc } \\
=\text { total petroleu }\end{array}$ & $\begin{array}{l}\text { ifference } \\
\text { drocarbon }\end{array}$ & \\
\hline
\end{tabular}

a Detection limits shown are "nominal" maximums. Most analytes will achieve this or a lower detection limit. A limited number will have higher detection limits.

${ }^{b}$ Alternative methods for evaluation of bacteria are being investigated. 


\subsubsection{Field Measurements}

Field measurements are performed using portable instruments to evaluate vadose zone porespace vapor samples during well drilling and performance of bioventing pilot tests. The instruments are calibrated and operated in accordance with the manufacturer's specifications and SOPs. Table 3 provides a list of field analytical methods.

Table 3. Analytical Performance Requirements - Field Measurements.

\begin{tabular}{|l|l|c|l|}
\hline \multicolumn{1}{|c|}{ Analytical Method } & \multicolumn{1}{|c|}{ Analyte } & $\begin{array}{c}\text { Instrument } \\
\text { Response }\end{array}$ & \multicolumn{1}{c|}{ Calibration } \\
\hline $\mathrm{O}_{2} / \mathrm{CO}_{2}$ gas meter & Oxygen, carbon dioxide & 0 to $25 \%$ & $\begin{array}{l}\text { Calibrate daily using } \\
\text { atmospheric concentrations of } \\
\mathrm{O}_{2}(20.9 \%) \text { and } \mathrm{CO}_{2}(0.05 \%) \\
\text { and a gas standard containing } \\
0.0 \% \mathrm{O}_{2} \text { and } 5.0 \% \mathrm{CO}_{2}\end{array}$ \\
\hline $\begin{array}{l}\text { Combustible gas } \\
\text { indicator }\end{array}$ & Combustible gases & $\% \mathrm{LEL}$ & $\begin{array}{l}\text { Calibrate in accordance with } \\
\text { manufacturer recommendations }\end{array}$ \\
\hline $\begin{array}{l}\text { Photoionization } \\
\text { detector }\end{array}$ & Volatile organic compounds & $\mathrm{ppm}$ & $\begin{array}{l}\text { Calibrate in accordance with } \\
\text { manufacturer recommendations }\end{array}$ \\
\hline $\begin{array}{l}\text { Flame ionization } \\
\text { detector }\end{array}$ & Petroleum hydrocarbons & $<100 \mathrm{ppm}$ & $\begin{array}{l}\text { Be capable of distinguishing } \\
\text { between methane and } \\
\text { nonmethane; calibrate in } \\
\text { accordance with manufacturer } \\
\text { recommendations }\end{array}$ \\
\hline Water level & Depth to groundwater & $0.01 \mathrm{ft}$ & NA \\
\hline
\end{tabular}

NOTE: Field instrumentation used for the purpose of health and safety monitoring is operated and calibrated as specified in the applicable health and safety plan and procedures.

LEL = lower explosive limit

NA = not applicable

\subsection{SPECIAL TRAINING REQUIREMENTS AND CERTIFICATIONS}

Training or certification requirements needed by personnel are described in BSC-1, Business Services and Communications, Procedure BSC-1-2.4, "Training Requirements" and ENV-1, Environmental Monitoring \& Management, Procedure ENV-1 2.36, "River Corridor Quality Assurance Program Plans." Additional training requirements necessary for drilling personnel are specified in the subcontract for drilling services.

\subsection{MEASUREMENT/DATA ACQUISITION}

This section presents the sampling process design, along with the requirements for sampling methods, sample handling, custody, preservation, containers, and holding times. The requirements for field and laboratory $\mathrm{QC}$, instrument calibration and maintenance, and field documentation are also addressed.

Sampling and Analysis Instruction for Installation of UPR-100-N-17 Bioremediation Wells and Performance of Bioventing Pilot Tests 


\subsection{VADOSE ZONE SOIL SAMPLING}

During well drilling to install the bioventing wells, vadose zone soil samples will be obtained for geologic logging, field screening, and laboratory analyses. The project analytical lead/field geologist is responsible for implementation and documentation of data collection activities. If any technical changes are required based on conditions observed in the field, the project analytical lead/field geologist will notify the Project Lead.

\subsubsection{Geologic Logging}

Grab soil samples will be collected from the drive barrel at $1.5 \mathrm{~m}(5-\mathrm{ft})$ intervals and inspected by the project analytical lead/field geologist for geologic logging purposes. The grab sample will be provided to The $\mathrm{CH} 2 \mathrm{M}$ Hill Plateau Remediation Contractor (CHPRC) for soil archival, if requested. Geologic logging of the borehole and associated documentation will be conducted concurrently with the drilling by the WCH analytical lead/geologist using CHPRC Groundwater Remediation Project Procedure, Procedure GRP-EE-01-7.0, "Geologic Logging," or equivalent documentation. Data to be recorded will include soil sample interval, sample recovery, visual presence or absence of contamination, soil description, and lithology. The depth to groundwater will be measured and documented for deep vadose wells.

\subsubsection{Split-Spoon Soil Sample Collection}

A minimum of two split-spoon soil samples will be collected from each borehole for laboratory analyses. Soil sampling will be performed in accordance with ENV-1, Procedure ENV-1 2.16, "Soil and Sediment Sampling." Samples will be collected using an $11.43 \mathrm{~cm}$ (4.5-in.) innerdiameter split-spoon sampler equipped with four $15.2 \mathrm{~cm}$ (6-in.)-long separate stainless steel liners for samples. If insufficient soil is retrieved in the split spoon to satisfy the volumetric requirements for sample analysis, the split-spoon may be redriven or additional material retrieved from the drive barrel. An entry will be made in the borehole log and the field logbook identifying the sample collection method and depth intervals. All split-spoon sampling depths will be referenced to the maximum depth that the split spoon is driven. All depths will be recorded to the nearest $0.025 \mathrm{~m}(0.10 \mathrm{ft})$. Drilling personnel will not overdrive the sampling device.

The split spoon sampler and liners will be decontaminated by CHPRC nuclear process operators (NCOs) before use in accordance with CHPRC Groundwater Remediation Project Procedure, GRP-EE-01-6.2, "Field Cleaning and/or Decontamination of Drilling Equipment."

For each of the five deep wells, one split-spoon soil sample will be collected from immediately above the water table in the capillary fringe (approximately $12.3 \mathrm{~m} \mathrm{[70} \mathrm{ft])} \mathrm{and} \mathrm{one} \mathrm{from} 1.5 \mathrm{~m}$ (5 ft) above the water table. Actual sample intervals for each borehole may vary depending upon depth to groundwater. For the two shallow wells, split-spoon soil samples will be collected at

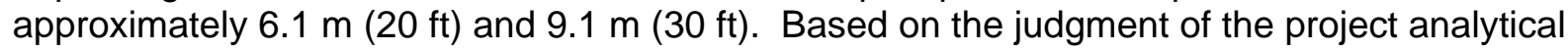
lead/site geologist, additional or alternative split-spoon samples may be collected at significant lithologic changes or at areas exhibiting contamination. The split-spoon soil samples will be submitted for analysis of colony forming units (CFU) to assess the presence of microorganisms; soil $\mathrm{pH}$ and moisture to determine if growth conditions are adequate; and carbon (as total organic carbon), nitrogen, and phosphorous to determine if nutrient ranges are acceptable. Results of these tests will not assure or rule-out bioventing remediation but will indicate if vadose conditions are amenable for microorganism growth. Soil samples will also be analyzed for gasoline, diesel

Sampling and Analysis Instruction for Installation of UPR-100-N-17 Bioremediation Wells and Performance of Bioventing Pilot Tests

December 2008 
oil, motor oil, BTEX, (RCRA) metals, hexavalent chromium, and strontium-90 to determine the concentration and distribution of contaminants. Table 4 provides a summary of the split-spoon sample collection intervals for each well and the laboratory analysis that will be performed for each sample.

Table 4. Vadose Zone Soil Sampling Requirements.

\begin{tabular}{|c|c|c|c|c|c|}
\hline \multirow{2}{*}{$\begin{array}{l}\text { Well } \\
\text { Type }\end{array}$} & \multicolumn{2}{|c|}{ Location } & \multirow{2}{*}{$\begin{array}{c}\text { Designed } \\
\text { Screened } \\
\text { Interval (bgs) }\end{array}$} & \multirow{2}{*}{$\begin{array}{c}\text { Split-Spoon } \\
\text { Sample Interval }^{\mathrm{a}} \\
\text { (bgs) }\end{array}$} & \multirow[b]{2}{*}{ Sample Analysis } \\
\hline & $\begin{array}{l}\text { Northing } \\
\text { (m) }\end{array}$ & Easting (m) & & & \\
\hline DIW-1 & 149698.263 & 571296.698 & $\begin{array}{c}15.2-21.3 \mathrm{~m}^{\mathrm{a}} \\
(50-70 \mathrm{ft})\end{array}$ & $\begin{array}{l}19.8 \mathrm{~m}(65 \mathrm{ft}) \\
21.3 \mathrm{~m}(70 \mathrm{ft})\end{array}$ & \multirow{7}{*}{$\begin{array}{l}\text { TPH-diesel } \\
\text { TPH-gasoline } \\
\text { TPH-motor oil } \\
\text { Oil and grease } \\
\text { VOA (BTEX) } \\
\text { TOC } \\
\text { RCRA metals } \\
\text { CrVI } \\
\text { pH } \\
\text { Sr-90 } \\
\text { Moisture content } \\
\text { Bacteria CFU } \\
\text { Nitrogen } \\
\text { Phosphorous }\end{array}$} \\
\hline DMP-1 & 149705.552 & 571293.792 & $\begin{array}{c}15.2-21.3 \mathrm{~m}^{\mathrm{b}} \\
(50-70 \mathrm{ft})\end{array}$ & $\begin{array}{l}19.8 \mathrm{~m}(65 \mathrm{ft}) \\
21.3 \mathrm{~m}(70 \mathrm{ft})\end{array}$ & \\
\hline DMP-2 & 149714.927 & 571288.563 & $\begin{array}{c}15.2-21.3 \mathrm{~m}^{\mathrm{b}} \\
(50-70 \mathrm{ft})\end{array}$ & $\begin{array}{l}19.8 \mathrm{~m}(65 \mathrm{ft}) \\
21.3 \mathrm{~m}(70 \mathrm{ft})\end{array}$ & \\
\hline DMP-3 & 149724.362 & 571283.418 & $\begin{array}{c}15.2-21.3 \mathrm{~m}^{\mathrm{b}} \\
(50-70 \mathrm{ft})\end{array}$ & $\begin{array}{l}19.8 \mathrm{~m}(65 \mathrm{ft}) \\
21.3 \mathrm{~m}(70 \mathrm{ft})\end{array}$ & \\
\hline DMP-4 & 149744.129 & 571258.652 & $\begin{array}{c}15.2-21.3 \mathrm{~m}^{\mathrm{a}} \\
(50-70 \mathrm{ft})\end{array}$ & $\begin{array}{l}19.8 \mathrm{~m}(65 \mathrm{ft}) \\
21.3 \mathrm{~m}(70 \mathrm{ft})\end{array}$ & \\
\hline SIW-1 & 149695.864 & 571292.082 & $\begin{array}{l}3-9.1 \mathrm{~m}^{\mathrm{a}} \\
(10-30 \mathrm{ft})\end{array}$ & $\begin{array}{l}6.1 \mathrm{~m}(20 \mathrm{ft}) \\
9.1 \mathrm{~m}(30 \mathrm{ft})\end{array}$ & \\
\hline SMP-1 & 149713.145 & 571286.069 & $\begin{array}{c}3-9.1 \mathrm{~m}^{\mathrm{b}} \\
(10-30 \mathrm{ft})\end{array}$ & 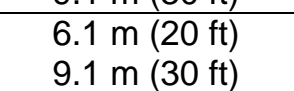 & \\
\hline
\end{tabular}

${ }^{\text {a }}$ Sample intervals are approximate and may be adjusted based on depth to groundwater.

b See Table 3 for list of analytical methods to be performed for all split-spoon soil samples.

bgs = below ground surface

$\mathrm{TPH}=$ total petroleum hydrocarbon

$\mathrm{CFU}=$ colony forming unit

TOC = total organic carbon

RCRA $=$ Resource Conservation and Recovery Act of 1976

VOA = volatile organic analytes

\subsubsection{Field Screening}

Field screening for the purpose of health and safety monitoring will be performed as required by the site-specific health and safety document prepared for the drilling activity. Field screening to supplement vadose zone soil samples will be performed as needed at selected drilling intervals. A nonslough portion of the soil sample may be collected from the drive barrel and field screened to check for indications of the presence of VOCs and separate-phase hydrocarbons. Monitoring may include using a photoionization detector (PID) to test for the presence of VOCs and a FID to monitor for petroleum hydrocarbons depending upon field conditions. The PID/FID will be calibrated in accordance with the manufacturer's recommendation and the applicable SOP.

For PID/FID screening, a portion of the soil sample will be placed in a Ziploc ${ }^{\mathrm{TM}}$-type plastic bag, sealed, disaggregated, and allowed to sit undisturbed for approximately 10 minutes. The PID/FID inlet tube will then be inserted into the bag and the highest observed reading will be recorded. The results of field screening will be recorded in the field logbook and on the borehole logs.

\subsubsection{Geophysical Well Logging}

At the completion of drilling and sampling and prior to installation of well casing, the 20 -cm (8-in.)diameter boreholes will be logged using high-resolution spectral gamma ray and neutron moisture

Sampling and Analysis Instruction for Installation of UPR-100-N-17 Bioremediation Wells and Performance of Bioventing Pilot Tests

December 2008 
sonde. High-resolution spectral gamma-ray logs are useful to evaluate the vertical distribution and concentration of gamma-emitting radionuclides. Neutron moisture logs are used to assess the vertical distribution of moisture in the soil column at the site.

\subsection{SOIL GAS MEASUREMENTS}

This section provides a description of the basic soil gas bioventing tests that will be performed. A summary of the use of the data and calculations that are performed is also described. The soil gas measurements consists of a three-step process:

1. Initial Soil Gas Measurement: Baseline conditions of oxygen, carbon dioxide, and volatile organic hydrocarbons are determined from soil gas measurements.

2. Respirometry Test: After air is injected into the deep and shallow injection wells, soil gas measurements are collected from monitoring wells to estimate the rate of oxygen uptake in the soil gas (in situ respiration rate).

3. Air Injection Test: Air injection tests are performed to determine the extent and rate of oxygen movement into the surrounding soil, providing an estimate of the radius of pressure and oxygen influence.

Procedures for performance of the soil gas measurements will be developed by the bioventing subcontractor and submitted to the contractor for approval. Field conditions and observations of changing conditions as the testing proceeds will require flexibility in testing procedures and data collection. The subcontractor will consult with the contractor during testing and if modifications are needed.

\subsubsection{Data Collection and Reduction}

The subcontractor responsible for performing the bioventing pilot tests will document all field data collection as prescribed in procedures approved by the contractor. The data will be used for calculations to support evaluation of bioventing as a treatment for petroleum hydrocarbons in the vadose zone and subsequent design of a potential full-scale treatment system, if warranted. The following is a summary of the parameters that are determined using the bioventing pilot test data:

- The baseline soil sample and soil gas results are used to support determining the areas and depth intervals exhibiting the most contamination that would benefit from bioventing.

- The radius of oxygen influence is determined using measurements of pressure response and soil gas chemistry at monitoring wells during the air injection tests.

- The rate of oxygen utilization is the key data produced from the in-situ respiration test and supports calculation of the rate of biodegradation. Carbon dioxide production is of interest, and is documented. Figure 8 (reproduced from AFCEE 2004 for this document) illustrates the common method of analyzing oxygen utilization data. Excel or similar spreadsheet and graphing software can be used to plot and analyze the oxygen verses time data for each monitoring point. The $\mathrm{K}_{\mathrm{o}}$ value is calculated from the slope of the line and assumes a "zero order" relationship because oxygen is not limiting the biodegradation. The plot of oxygen data shows a rapid linear decrease in oxygen followed by a "flattening" of the oxygen utilization

Sampling and Analysis Instruction for Installation of UPR-100-N-17 Bioremediation Wells and Performance of Bioventing Pilot Tests

December 2008 
slope once the oxygen drops below $5 \%$. This is common in very contaminated soils because at lower oxygen concentrations, oxygen may begin to limit the rate of biodegradation. The steep linear portion of the oxygen utilization curve is used to calculate the $\mathrm{K}_{\mathrm{o}}$ and the rate of biodegradation. In the figure, at MPA-10 (sample location in example), a $\mathrm{K}_{\mathrm{o}}$ of $29 \%$ per day was calculated. For MPB-5 (sample location in example), a $\mathrm{K}_{\mathrm{o}}$ of $4.3 \%$ per day was calculated. In this example, MPA-10 has a high $\mathrm{K}_{0}$ because it was located near the center of the fuel spill and within the highly contaminated smear zone at $3 \mathrm{~m} \mathrm{(10} \mathrm{ft)} \mathrm{bgs.} \mathrm{A} \mathrm{lower} \mathrm{K}_{\mathrm{o}}$ was observed at MPB-5. MPB-5 was located in a less contaminated area. It is not uncommon for the rate of oxygen utilization to vary by more than an order of magnitude at the same site. Higher $\mathrm{K}_{\mathrm{o}}$ values are commonly recorded in soils with higher levels of hydrocarbon contamination which support larger populations of bacteria.

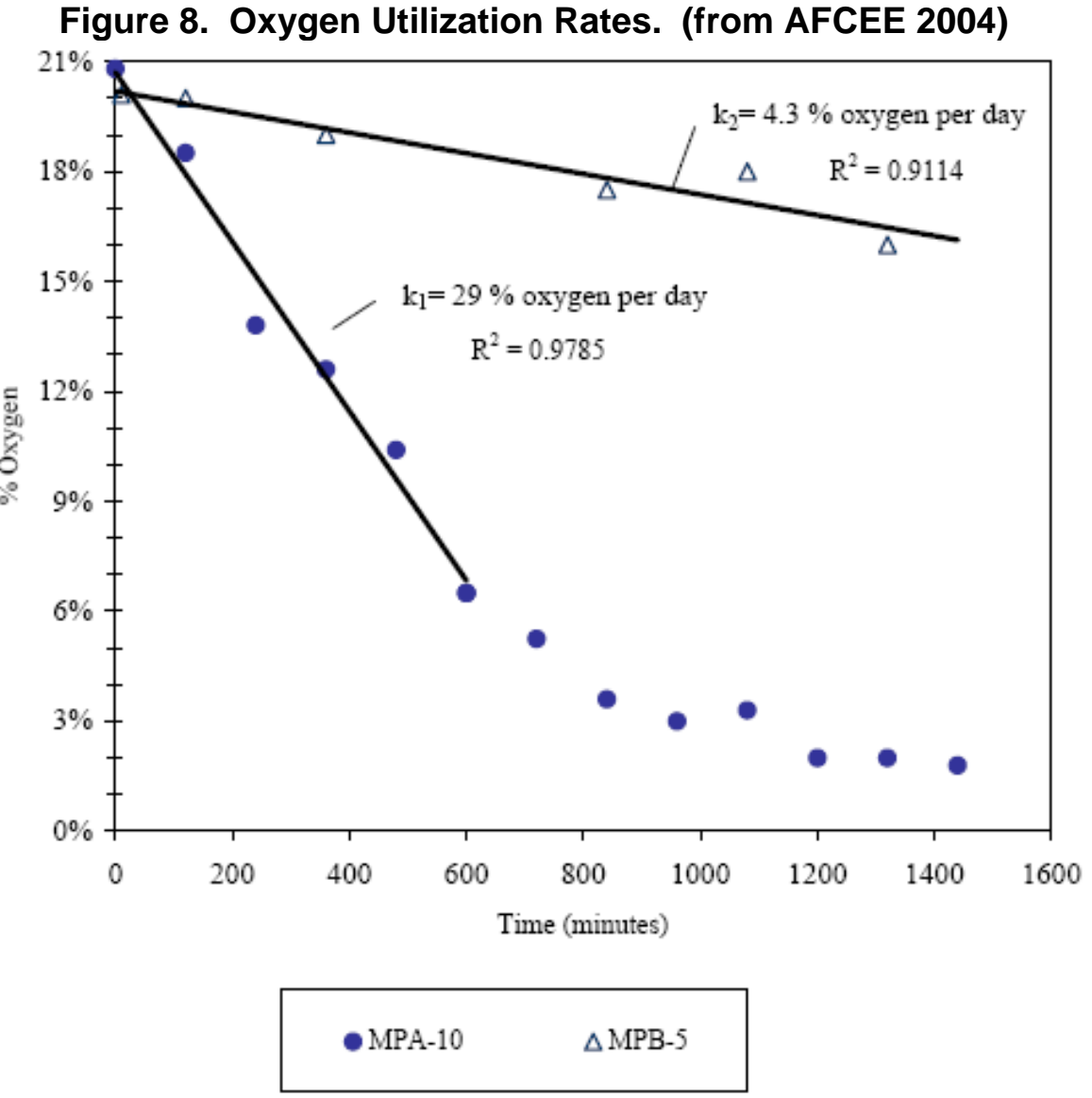

\subsection{FIELD DOCUMENTATION AND SAMPLE MANAGEMENT}

\subsubsection{Field Documentation}

Field documentation shall be kept in accordance with ENV-1, including the following procedures:

- Procedure ENV-1-2.5, "Field Logbooks"

- Procedure ENV-1.2.13, "Chain of Custody"

Sampling and Analysis Instruction for Installation of UPR-100-N-17 Bioremediation Wells and Performance of Bioventing Pilot Tests 
Geologic logging of the borehole and associated documentation will be conducted concurrently with the drilling by the WCH analytical lead/geologist using CHPRC Groundwater Remediation Project Procedure, Procedure GRP-EE-01-7.0, "Geologic Logging," or equivalent documentation.

\subsubsection{Sample Custody and Transport}

All sample handling, shipping, and custody will be performed in accordance with ENV-1, including the following procedures:

- Procedure ENV-1.2.13, "Chain of Custody"

- Procedure ENV-1.2.14, "Sample Packaging and Shipping".

\subsubsection{Sample Preservation, Containers, and Holding Times}

The sample preservation, container, and holding time requirements for the analyses to be performed are summarized in Table 5.

Table 5. Sample Preservation, Container, and Holding Time Guidelines. (2 pages)

\begin{tabular}{|c|c|c|c|c|c|}
\hline Parameter & Method & $\begin{array}{l}\text { Bottle } \\
\text { Type }\end{array}$ & Amount & Preservation & $\begin{array}{l}\text { Holding } \\
\text { Time }\end{array}$ \\
\hline Gasoline & $\begin{array}{c}\text { TPH - Gasoline Range } \\
\text { (WTPH-G) }\end{array}$ & G & $125 \mathrm{~g}$ & $\mathrm{Cool} 4^{\circ} \mathrm{C}$ & 14 days \\
\hline Diesel oil & $\begin{array}{l}\text { TPH - Diesel Range } \\
\text { (WTPH-D) }\end{array}$ & G & $125 \mathrm{~g}$ & $\mathrm{Cool} 4^{\circ} \mathrm{C}$ & 14 days \\
\hline Motor oil & $\begin{array}{c}\text { TPH - Motor Oil } \\
\text { Range (WTPH - Dx) }\end{array}$ & G & $125 \mathrm{~g}$ & $\mathrm{Cool} 4^{\circ} \mathrm{C}$ & 14 days \\
\hline VOA (BTEX) & EPA Method 8260 & $\mathrm{aG}$ & $125 \mathrm{~g}$ & $\mathrm{Cool} 4^{\circ} \mathrm{C}$ & 14 days \\
\hline Oil and grease & EPA Method 9070 & G & $500 \mathrm{~g}$ & $\mathrm{Cool} 4^{\circ} \mathrm{C}$ & 28 days \\
\hline RCRA metals & EPA Method 6010 & $P / G$ & $250 \mathrm{~g}$ & $\mathrm{Cool} 4^{\circ} \mathrm{C}$ & 180 days \\
\hline Hexavalent chromium & EPA Method 7196 & $P / G$ & $125 \mathrm{~g}$ & $\mathrm{Cool} 4^{\circ} \mathrm{C}$ & 30 days \\
\hline Total organic carbon & EPA Method 9060 & $\mathrm{aG}$ & $125 \mathrm{~g}$ & $\mathrm{Cool} 4^{\circ} \mathrm{C}$ & 28 days \\
\hline Strontium-90 & Liquid scintillation & $P / G$ & $15 \mathrm{~g}$ & None & None \\
\hline Moisture content & ASTM D2216 & $\begin{array}{c}\text { Moisture } \\
\text { Tin }\end{array}$ & $1000 \mathrm{~g}$ & None & None \\
\hline $\begin{array}{l}\text { Heterotrophic bacterial plate } \\
\text { count }\end{array}$ & SM 9215.D & $\begin{array}{l}\text { Whirl- } \\
\text { Pak }{ }^{2}\end{array}$ & $200 \mathrm{~g}$ & $\mathrm{Cool} 4^{\circ} \mathrm{C}$ & None \\
\hline $\begin{array}{l}\text { Total Kjeldahl Nitrogen } \\
(\text { TKN) }\end{array}$ & EPA Method 351.N & $P / G$ & $300 \mathrm{~g}$ & $\mathrm{Cool} 4^{\circ} \mathrm{C}$ & 28 days \\
\hline EPA Method 350.1 & $\begin{array}{l}\mathrm{NH}_{3}-\mathrm{N} \text { Nitrogen in } \\
\text { Ammonia }\end{array}$ & $P / G$ & $300 \mathrm{~g}$ & $\mathrm{Cool} 4^{\circ} \mathrm{C}$ & 28 days \\
\hline
\end{tabular}

Sampling and Analysis Instruction for Installation of UPR-100-N-17 Bioremediation Wells and Performance of Bioventing Pilot Tests

December 2008 
Table 5. Sample Preservation, Container, and Holding Time Guidelines. (2 pages)

\begin{tabular}{|c|c|c|c|c|c|}
\hline Parameter & Method & $\begin{array}{c}\text { Bottle } \\
\text { Type }\end{array}$ & Amount & Preservation & $\begin{array}{c}\text { Holding } \\
\text { Time }\end{array}$ \\
\hline Anions, $\mathrm{NO}_{2}, \mathrm{NO}_{3}, \mathrm{P}_{3} \mathrm{O}_{4}$ & EPA Method 300.0 & $P / G$ & $125 \mathrm{~g}$ & Cool $4^{\circ} \mathrm{C}$ & 48 hours \\
\hline Corrosivity $(\mathrm{pH})$ & EPA Method 9045 & P/G & $250 \mathrm{~g}$ & Cool $4^{\circ} \mathrm{C}$ & ASAP \\
\hline $\begin{array}{ll}\mathrm{aG} & =\text { amber glass } \\
\mathrm{ASAP} & =\text { as soon as possible } \\
\mathrm{G} & =\text { glass } \\
\mathrm{P} & =\text { plastic }\end{array}$ & $\begin{array}{ll}\text { RCRA } & =\text { Resource } \\
\text { TBD } & =\text { to be deter } \\
\text { VOA } & =\text { volatile org }\end{array}$ & $\begin{array}{l}\text { servation } \\
\text { led } \\
\text { c anaytes }\end{array}$ & רd Recov & ery Act of 1976 & \\
\hline
\end{tabular}

\subsubsection{Equipment Decontamination}

The split-spoon sampler and liners will be decontaminated by CHPRC NPOs before use in accordance with CHPRC's Groundwater Remediation Project Procedure, GRP-EE-01-6.2, "Field Cleaning and/or Decontamination of Drilling Equipment."

\subsection{QUALITY CONTROL REQUIREMENTS}

The QC procedures must be followed in the field and laboratory to ensure that reliable data are obtained. When performing this field sampling effort, care shall be taken to prevent the cross-contamination of sampling equipment, sample bottles, and other equipment that could compromise sample integrity.

\subsubsection{Field Quality Control}

Field QC samples will consist of the following:

- One field duplicate soil sample shall be collected and analyzed per Table 3 of this document. The duplicate sample shall be collected from the same split-spoon interval as the main sample, if sufficient sample media is present. If insufficient sample media is available for collection of both the primary and duplicate sample, then additional soil may be collected from the drive barrel taken at the same sample depth interval and combined with the soil from the split spoon sample.

- One equipment blank will be collected to evaluate the adequacy of sampling equipment decontamination procedures. The project analytical lead/field geologist may collect additional equipment blanks if deemed necessary. The equipment blank will consist of silica sand that is poured over the sampling equipment that will come in direct contact with the sample media submitted for laboratory analysis. The equipment blank will be analyzed for volatile organic analytes (BTEX), inductively coupled plasma metals, TPH-diesel, TPH-gasoline, TPH-motor oil, and total organic carbon.

- Split soil samples and trip blanks are not required.

Sampling and Analysis Instruction for Installation of UPR-100-N-17 Bioremediation Wells and Performance of Bioventing Pilot Tests 


\subsubsection{Laboratory Quality Control}

Laboratory QC requirements will be performed as specified in the analytical services statement of work for the selected laboratory. Laboratory QC will consist of a laboratory method blank, laboratory control sample, matrix spike and laboratory duplicate or matrix spike duplicate.

\subsection{INSTRUMENT CALIBRATION AND MAINTENANCE}

Analytical instrument calibration and maintenance is conducted in accordance with the QC requirements identified in each laboratory SOP and QA plan, and the manufacturer's instructions. Field instrumentation requirements specified in this section are applicable only to measurements performed as part of site characterization and pilot study data collection. Requirements for field instruments used for the purpose of health and safety monitoring are specified in health and safety plans and associated instrument procedures.

\subsubsection{Field Measurement Instruments}

All calibration procedures and measurements will be made in accordance with manufacturers' specifications and contractor SOPs. Field instruments will be checked and calibrated before their use on site, and batteries will be charged and checked daily where applicable. Instrument calibration will be checked at the beginning of each workday and checked and recalibrated if necessary through the course of the day according to manufacturers' specifications or if deemed necessary by sampling personnel. Equipment that fails calibration and/or becomes otherwise inoperable during the field investigation will be removed and either repaired or replaced.

All documentation pertinent to the calibration and/or maintenance of field measurement equipment will be recorded in a field logbook. Logbook entries regarding the status of field equipment will contain, but will not necessarily be limited to, the following information:

- Date and time of calibration

- Name of person conducting calibration

- Type of equipment being calibrated (make and model)

- Reference standard used for calibration

- Other pertinent information.

\subsubsection{Laboratory Instruments}

Calibration of laboratory analytical instrumentation will be performed in accordance with the requirements specified in the contracted laboratory SOPs and QA plan.

\subsection{DATA VALIDATION AND VERIFICATION}

Data verification and validation are performed on analytical data sets primarily to confirm that sampling and chain-of-custody documentation is complete, sample numbers can be tied to the specific sampling location, samples were analyzed within the required holding times, and analyses met the data quality requirements specified in this SAI. For this investigation, data verification will be performed; however, data validation will not be required.

Sampling and Analysis Instruction for Installation of UPR-100-N-17 Bioremediation Wells and Performance of Bioventing Pilot Tests

December 2008 


\subsection{ASSESSMENTS AND RESPONSE ACTIONS}

The Compliance and Quality Programs group may conduct random surveillance and assessments in accordance with QA-1, Quality Assurance, Procedure QA-1-1.5, "Self-Assessment," to verify compliance with the requirements outlined in this SAI, project work packages, WCH procedures, and regulatory requirements.

Deficiencies identified by one of these assessments shall be reported in accordance with QA-1, Procedure QA-1-1.2, "Corrective Action Management." When appropriate, corrective actions will be taken by the project engineer in accordance with the Hanford Analytical Services Quality Assurance Requirements Document, Vol. 1, Section 4.0 (DOE-RL 1996a), to minimize recurrence.

\subsection{WASTE MANAGEMENT}

Waste generated by sampling activities will be managed in accordance with the Remedial Design Report/Remedial Action Work Plan for the 100-N Area (DOE-RL 2006b) and WMT-1, Waste Management and Transportation. However, borehole drill cuttings, which were not specifically addressed in the RDR/RAWP, will be collected for disposal at The Environmental Restoration Disposal Facility (ERDF). If petroleum contamination is present in the borehole drill cuttings and the cuttings meet the ERDF waste acceptance criteria, cuttings will be disposal at ERDF.

Unused samples and associated laboratory waste for the analysis will be dispositioned in accordance with the laboratory contract and agreements for return to the Hanford Site. Pursuant to 40 Code of Federal Regulations (CFR) 300.440, Remedial Project Manager (RPM) approval is required before returning unused samples or waste from offsite laboratories located off the Hanford Site.

In addition, RPM approval must be obtained before shipping sample waste from laboratories on the Hanford Site back to the waste site of origination. This approval may be obtained via the RPM's approval of this SAI.

Purgewater resulting from equipment decontamination and groundwater sampling will be managed in accordance with the Strategy for Handling and Disposing of Purgewater at the Hanford Site, Washington (DOE-RL 1990). Groundwater sampling is not performed for the bioventing pilot system vadose wells.

\subsection{HEALTH AND SAFETY}

All field operations will be performed in accordance with $\mathrm{WCH}$ health and safety requirements, which are outlined in SH-1, Safety and Health, and RC-1, Radiation Protection Procedures. A site-specific health and safety plan and job safety analysis for drilling operations will be prepared by the drilling subcontractor.

Sampling and Analysis Instruction for Installation of UPR-100-N-17 Bioremediation Wells and Performance of Bioventing Pilot Tests

December 2008 
The sampling procedures and associated activities will consider exposure reduction and contamination control techniques that will minimize the radiation exposure to the sampling team as required by RC-1 and QA-1, Quality Assurance.

\subsection{REFERENCES}

40 CFR 300, "National Oil and Hazardous Substances Pollution Contingency Plan," Code of Federal Regulations, as amended.

AFCEE, 2004, Procedures for Conducting Bioventing Pilot Tests and Long-Term Monitoring of Bioventing Systems, U.S. Air Force, San Antonio, Texas.

BSC-1, Business Services and Communications, Washington Closure Hanford, Richland, Washington.

DOE 414.1A, Quality Assurance, as amended, U.S. Department of Energy, Washington D.C.

DOE-RL, 1990, Strategy for Handling and Disposing of Purgewater at the Hanford Site, Washington, Letter No. 90-ERB-076 from R. O. Izatt, U. S. Department of Energy, to Hanford Site Contractors, dated August 21, 1990.

DOE-RL, 1995, Limited Field Investigation Report for the 100-NR-1 Operable Unit Abatement Assessment, DOE/RL-93-80, Rev. 0, U.S. Department of Energy, Richland Operations Office, Richland, Washington.

DOE-RL, 1996a, Hanford Analytical Services Quality Assurance Requirements Documents, DOE/RL-96-68, Rev. 0, U.S. Department of Energy, Richland Operations Office, Richland, Washington.

DOE-RL, 1996b, 1301-N and 1325-N Liquid Waste Disposal Facilities Limited Field Investigation Report, DOE/RL-96-11, Rev. 0, U.S. Department of Energy, Richland Operations Office, Richland, Washington.

DOE-RL, 1996c, RCRA Facility Investigation/Corrective Measures Study Work Plan for the 100-NR-2 Operable Unit, Hanford Site, Richland, Washington, DOE/RL-91-46, Rev. 0, U.S. Department of Energy, Richland Operations Office, Richland, Washington.

DOE-RL, 2006a, 100-N Area Sampling and Analysis Plan for CERCLA Waste Sites, DOE/RL-2005-92, Rev. 0, U.S. Department of Energy, Richland Operations Office, Richland, Washington.

DOE-RL, 2006b, Remedial Design Report/Remedial Action Work Plan for the 100-N Area, DOE/RL-2005-93, Rev. 0, U.S. Department of Energy, Richland Operations Office, Richland, Washington.

Sampling and Analysis Instruction for Installation of UPR-100-N-17 Bioremediation Wells and Performance of Bioventing Pilot Tests

December 2008 
DOE-RL, 2008, Hanford Site Groundwater Monitoring for Fiscal Year 2007, DOE/RL-2008-01, Rev. 0, U.S. Department of Energy, Richland Operations Office, Richland, Washington.

ENV-1, Environmental Monitoring \& Management, Washington Closure Hanford, Richland, Washington.

EPA, 1999, Interim Action Record of Decision for the 100-NR-1 and 100-NR-2 Operable Units, Hanford Site, Benton County, Washington, U.S. Environmental Protection Agency, Region 10, Seattle, Washington.

EPA, 2001, EPA Requirements for Quality Assurance Project Plans for Environmental Data Operations, EPA QA/R-5, U.S. Environmental Protection Agency, Washington, D.C.

GE, 1967, "Oil Leak - 100-N Area", letter dated June 27, 1967 from R.L. Dickeman, General Electric Company, to W. Devine, Jr., U. S. Atomic Energy Commission, Richland Operations Office, General Electric Company, Richland, Washington.

GRP-EE-01-6.2 Groundwater Remediation Project Procedure, "Field Cleaning and/or Decontamination of Drilling Equipment," Fluor Hanford, Inc., Richland, Washington.

GRP-EE-01-7.0, Groundwater Remediation Project Procedure, "Geologic Logging," Fluor Hanford, Inc., Richland, Washington.

Hartman, M. J. and Lindsey, K. A., 1993, Hydrogeology of the 100-N Area, Hanford Site, Washington, WHC-SD-EN-EV-027, Rev. 0, Westinghouse Hanford Company, Richland, Washington.

RC-1, Radiation Protection Procedures, Washington Closure Hanford, Richland, Washington.

Resource Conservation and Recovery Act of 1976, 42 U.S.C. 6901 et seq.

SH-1, Safety and Health, Washington Closure Hanford, Richland, Washington.

QA-1, Quality Assurance, Washington Closure Hanford, Richland, Washington.

WAC 173-303, "Dangerous Waste Regulations," Washington Administrative Code, as amended.

WAC 173-160, "Minimum Standards for Construction and Maintenance of Wells," Washington Administrative Code, as amended.

WCH, 2006, "Post-Demolition Summary Report for the 166-N Fuel Oil Pump House, 166-N Fuel Oil Unloading Station, and the 1715-N Fuel Oil Storages Tanks 1-5," CCN 128258, Washington Closure Hanford, Richland, Washington.

WHC, 1994, 100-N Area Technical Baseline Report, WHC-SD-EN-TI-251, Rev. 0, Westinghouse Hanford Company, Richland, Washington.

WMT-1, Waste Management and Transportation, Washington Closure Hanford, Inc., Richland, Washington.

Sampling and Analysis Instruction for Installation of UPR-100-N-17 Bioremediation Wells and Performance of Bioventing Pilot Tests 


\section{DISTRIBUTION}

U.S. Department of Energy

$\underline{\text { Richland Operations Office }}$

T. C. Post

A3-04

J. C. Chance

A3-04

\section{CH2M HILL Plateau Remediation Company}

W. F. Barrett

E6-44

Pacific Northwest National Laboratory

D. P. Mendoza

K6-96

Washington Closure Hanford

T. M. Blakley

$\times 2-07$

R. A. Carlson

$\mathrm{X} 2-07$

S. W. Clark

$\mathrm{H} 4-23$

E. T. Feist

$\mathrm{H} 4-22$

D. A. Gamon

$\mathrm{X} 2-07$

R. T. Hynes

N3-20

C. R. Martinez

X3-40

M. G. Peloquin

$\mathrm{T} 2-03$

M. L. Proctor

$\mathrm{H} 4-23$

D. G. Saueressig

X5-50

D. A. St. John (2)

$\mathrm{H} 4-21$

W. S. Thompson (3)

$\mathrm{H} 4-23$

Washington State Department of Ecology

J. Price (2)

$\mathrm{H} 0-57$

Document Control (2)

$\mathrm{H} 4-11$

DOE-RL Public Reading Room

$\mathrm{H} 2-53$

Hanford Technical Library

P8-55 